\title{
Guarding the Genome: CENP-A-Chromatin in Health and Cancer
}

\author{
Megan A. Mahlke ${ }^{1,2}$ and Yael Nechemia-Arbely ${ }^{1,2, *(1)}$ \\ UPMC Hillman Cancer Center, Pittsburgh, PA 15213, USA; mahlkem@upmc.edu \\ 2 Department of Pharmacology and Chemical Biology, University of Pittsburgh, Pittsburgh, PA 15261, USA \\ * Correspondence: arbelyy@upmc.edu; Tel.: +1-412-623-3228; Fax: +1-412-623-7828
}

Received: 19 June 2020; Accepted: 15 July 2020; Published: 16 July 2020

\begin{abstract}
Faithful chromosome segregation is essential for the maintenance of genomic integrity and requires functional centromeres. Centromeres are epigenetically defined by the histone $\mathrm{H} 3$ variant, centromere protein A (CENP-A). Here we highlight current knowledge regarding CENP-A-containing chromatin structure, specification of centromere identity, regulation of CENP-A deposition and possible contribution to cancer formation and/or progression. CENP-A overexpression is common among many cancers and predicts poor prognosis. Overexpression of CENP-A increases rates of CENP-A deposition ectopically at sites of high histone turnover, occluding CCCTC-binding factor (CTCF) binding. Ectopic CENP-A deposition leads to mitotic defects, centromere dysfunction and chromosomal instability (CIN), a hallmark of cancer. CENP-A overexpression is often accompanied by overexpression of its chaperone Holliday Junction Recognition Protein (HJURP), leading to epigenetic addiction in which increased levels of HJURP and CENP-A become necessary to support rapidly dividing p53 deficient cancer cells. Alterations in CENP-A posttranslational modifications are also linked to chromosome segregation errors and CIN. Collectively, CENP-A is pivotal to genomic stability through centromere maintenance, perturbation of which can lead to tumorigenesis.
\end{abstract}

Keywords: CENP-A; centromere; chromosome segregation; mitosis; epigenetic; kinetochore; CIN; cancer

\section{Introduction}

Equal chromosome segregation during mitosis is critical for ensuring genome stability and for successful transmission of the genetic material to the daughter cells. The centromere is the central genetic element responsible for faithful chromosome inheritance during mitosis. Loss of centromere identity and/or function can have detrimental consequences, including errors in chromosome segregation, in the form of misaligned and lagging chromosomes. Such chromosome segregation errors often lead to micronuclei formation and may result in aneuploidy, the presence of additional or fewer chromosomes. Sustained high levels of mitotic defects may ultimately lead to chromosomal instability (CIN), a condition prevalent among many cancers. Cancers are frequently aneuploid [1-4], and the specific loss or gain of tumor suppressors and oncogenes associated with changes in chromosome number may contribute to tumorigenesis, malignancy, frequency of metastasis, and overall patient prognosis $[3,5,6]$. In this review we will highlight recent advances in understanding centromere maintenance and propagation in health and tumorigenesis.

Known as the centromere paradox, centromeric DNA sequence is not conserved between species despite functional conservation [7]. In humans, the centromere is composed of extensive tandemly repeated arrays of a 171-bp DNA sequence element called $\alpha$-satellite [8-10], organized into high-order repeat arrays (HOR), most of which can be uniquely assigned to specific chromosomes [10-13]. Centromeric $\alpha$-satellite DNA sequences represent $\sim 2-3 \%$ of the human genome $[12,14,15]$, and can 
vary between individuals in a population through acquisition of rearrangements and/or repeat expansions [16]. Despite the fact that human centromeres are found in this unique and complex genomic location, $\alpha$-satellite DNA sequences are neither sufficient nor essential for centromere identity $[8,17]$, as evidenced by the growing numbers of identified neocentromeres. Neocentromeres are defined by the acquisition of a new centromere at a new location coupled with inactivation of the original centromere [18]. Neocentromeres lack $\alpha$-satellite DNA but are epigenetically stable and can persist for several generations [18,19]. Centromere identity relies instead on epigenetic markers, with centromere protein A (CENP-A)-containing chromatin considered as the prime candidate, from yeast to human [20]. CENP-A is a centromere specific variant of the canonical histone H3, initially identified in humans [21,22], that marks, maintains and propagates centromere function indefinitely in human cells and fission yeast [23]. Knockout of CENP-A is embryonic lethal [24] and depletion or conditional knockout of CENP-A negatively impacts mitotic spindle pole integrity [25], resulting in increased rates of chromosome segregation errors [23,26].

As an epigenetic mark that identifies centromeres, tethering of CENP-A, or its depositing chaperone HJURP (Holliday Junction Recognition Protein), to a new genomic location can trigger local formation of a functional kinetochore in yeast [27], fly [28-30] and human [31,32], measured by recruitment of centromere and kinetochore proteins and by the ability to bind microtubules [28,31]. Studies in Human artificial chromosomes (HACs) have shown that HAC formation requires human $\alpha$-satellite centromeric repeats, high density of CENP-B boxes [33,34] and CENP-B expression [35]. Logsdon and colleagues have recently improved HAC technology bypassing the need for $\alpha$-satellite centromeric repeats and CENP-B boxes and instead using the epigenetic machinery to initiate centromere identity $[32,36]$. By tethering HJURP to a unique genomic location using the LacI-LacO system, they drove initial CENP-A nucleosome seeding, leading to stable centromere and HAC formation and resulting in a new generation of HACs built without $\alpha$-satellite DNA [32].

\section{The Structure and Composition of CENP-A-Containing Chromatin}

CENP-A is a rare histone variant that represents only $\sim 0.1 \%$ of the total histone $\mathrm{H} 3$ variants in the genome [37], while marking all active centromeres, including neocentromeres [17]. Centromeric chromatin is comprised of both CENP-A- and H3-containing nucleosomes [38,39]. While most ( 97\%) of the centromeric nucleosomes contain histone H3.1 [14], about 3-4\% are assembled with CENP-A, representing 200 CENP-A-containing nucleosomes per centromere on average [37].

The structure and composition of CENP-A-containing chromatin has been highly controversial (summarized in Black and Cleveland [40]) with prominent models including a conventional octameric nucleosome with 2 molecules each of CENP-A, H4, H2A and H2B [41,42] with a similar structure to histone H3-containing chromatin [43], a hemisome with only one molecule of each histone [44-46], a tetrasome lacking H2A and H2B [47], or a heterotypic nucleosome with one molecule of H3 and one molecule of CENP-A [48,49]. Another prominent model for CENP-A-containing chromatin suggested that CENP-A chromatin oscillates between two forms; a hemisome during G2, M and G1 transforming into an octameric nucleosome during $S$ phase [50]. Advances made in recent years using a plethora of approaches have demonstrated that the overwhelming majority of CENP-A molecules assemble into homotypic, octameric nucleosomes, containing two molecules of CENP-A [51], H4, H2A and H2B [52] at all cell cycle points [14] with heterotypic CENP-A/histone H3-containing nucleosomes comprising at most $2 \%$ of CENP-A-containing chromatin [14]. The main feature that differentiates CENP-A-from H3-containing nucleosomes is the highly flexible DNA ends at the entry and exit sites of CENP-A-containing nucleosomes [43,53-55]. This is consistent with studies showing transient DNA unwrapping at these regions [48,56,57] at all cell cycle points [14], mediated by the CENP-A N-terminal tail and the CENP-A targeting domain (CATD) [14]. This change in chromatin structure may have a role in producing a more global condensed chromatin state [58] while loosening CENP-A nucleosome DNA superhelical termini and allowing CENP-A nucleosomes to be readily accessible for binding of 
centromeric proteins [43]. In accordance with this idea, several recent (cryogenic Electron Microscopy) cryo-EM studies of the CENP-A nucleosome demonstrated higher flexibility and open conformation of the DNA ends [55], leading to a less twisted conformation in tri-nucleosomes composed of a central CENP-A nucleosome linked to two $\mathrm{H} 3$ nucleosomes than in $\mathrm{H} 3$ tri-nucleosomes, and yielding a highly exposed CENP-A nucleosome, readily accessible for binding kinetochore components [59]. Moreover, linker histones were shown to bind weakly and occur rarely at CENP-A-containing chromatin [55,60], again increasing accessibility of CENP-A for binding of centromeric proteins. Interestingly, enhanced cryo-EM structural imaging of the CENP-A nucleosome core particle revealed a key difference between the two DNA termini: one end shows well defined density and associates closely with the histone octamer core, whereas the other appears flexibly disordered and partly unwrapped [54].

\section{CENP-B Roles in Centromere Specification and Function}

Some centromeric repetitive $\alpha$-satellite DNA sequences contain a 17-bp motif [61] that serves as a binding site for CENP-B [21], the only sequence specific human centromere protein [61-63]. CENP-B plays a role in stabilizing centromere identity, through its direct interaction with both CENP-C and the N-terminal tail of CENP-A [23,64], as well as through its binding to the CENP-B box within $\alpha$-satellite DNA [65]. These bindings sustain and stabilize centromere/kinetochore assembly during mitosis even when CENP-A is depleted [66]. Indeed, abundance of CENP-B at individual centromeres is associated with higher segregation fidelity in the absence of CENP-A [67]. Despite the contribution of CENP-B to the stability of endogenous centromeres [66,67], CENP-B is not essential for centromere function, as CENP-B boxes are absent from the human $\mathrm{Y}$ centromere, and neocentromeres lacking $\alpha$-satellite DNA and CENP-B boxes are maintained through multiple cell divisions [68-70]. CENP-B is also absent from active centromeres at non-centromeric sites of dicentric chromosomes, and at centromeres of HACs lacking CENP-B boxes [17,19,32]. In addition, CENP-B knockout mice are viable [71-73] and CENP-B knockout cell lines can grow long-term [64], albeit with higher missegregation rates [64].

\section{The Constitutive Centromere-Associated Network Role in Kinetochore Assembly}

The centromeric chromatin provides a platform for binding of the constitutive centromere-associated network (CCAN) by adopting a higher order structure that partitions CENP-A nucleosomes towards the outer chromosome surface where they are maximally accessible for CCAN binding $[18,59,74-78]$. The CCAN is a large protein complex, consisting of 16 proteins, that links chromosomes and spindle microtubules by nucleating kinetochore assembly before mitotic entry. CCAN proteins are located in the inner kinetochore plate and distributed in several functional groups as follows: CENP-C, CENP-H/I/K, CENP-L/M/N, CENP-O/P/Q/R/U, CENP-T/W/S/X (for a detailed review see Hara and Fukagawa [79]).

Among the CCAN proteins, CENP-C is regarded as the blueprint for kinetochore assembly $[80,81]$. CENP-A uses its C-terminal tail [23] to bind CENP-C directly in two domains within CENP-C [82]. CENP-C binding to CENP-A stabilizes centromeric chromatin, reshapes the octameric histone core of CENP-A nucleosomes, rigidifies both surface and internal nucleosome structure, and unwraps the terminal DNA of CENP-A [83]. The unwrapping of the CENP-A nucleosome DNA ends facilitates further interaction with the CCAN [82]. Cyclin-dependent kinase (CDK)1-mediated phosphorylation of CENP-C facilitates its binding to CENP-A and CENP-A-CENP-C interaction is important for kinetochore localization of CENP-C during mitosis [84]. CENP-C serves as an anchor and a keystone protein that subsequently recruits other members of the CCAN, forming a stable platform for downstream kinetochore assembly [80,85-89]. Depletion of CENP-C results in loss of CENP-H///K/M, CENP-T, and NDC-80, leading to $\alpha$-satellite repeat instability [90], mitotic defects, and cell death $[80,83,85,91-95]$.

Interestingly, the activity of the small ubiquitin-like modifier (SUMO)-protease SENP6 was recently found to be required to maintain centromere and kinetochore integrity. SENP6 depletion 
leads to hyper-SUMOylation of CENP-C and CENP-I, and strong reduction of centromere-bound CENP-C, CENP-T, and CENP-A [96,97]. The KNL-1/Mis12 complex/Ndc80 complex (KMN)-network, NNF1, DSN1, and HEC1 are also reduced after SENP6 depletion [96]. The increase of SUMO chains does not lead to ubiquitin-dependent proteasomal degradation of the CCAN subunits, but to their delocalization [97]. Thus, the entire DNA-associated foundation of the centromere is under the critical control of SENP6 [96].

\section{Temporal Regulation of CENP-A Deposition: Precision in Action}

CENP-A deposition is a tightly regulated process to ensure that CENP-A assembles onto centromeric chromatin only once per cell cycle, although the cell cycle position during which centromeric chromatin is replicated varies in different species [98]. In higher eukaryotes, CENP-A deposition timing is dependent on passage through mitosis [98]. Surprisingly, the replication of centromeric chromatin is uncoupled from centromeric DNA replication. While human centromeric DNA replicates mostly in late $S$ phase $[12,99]$, the deposition and assembly of CENP-A onto the chromatin occurs after exit from mitosis [98,100,101], when its loading chaperone HJURP [102,103] is active [104,105] (Figure 1A). CENP-A assembly is directly linked to cell-cycle progression and is initiated during mitotic exit and restricted to the early G1 phase of the cell cycle. In human cells, HJURP localizes to centromeres at late anaphase/telophase and remains associated with centromeres during G1, the time window during which new CENP-A assembly occurs [102,103].

The targeting of CENP-A and HJURP to centromeres is dependent on the Mis18 complex, comprised of Mis18 $\alpha$, Mis18 $\beta$ and M18BP1. The human Mis18 complex localizes to centromeres at anaphase, just before HJURP, and remains associated until mid G1 [106-110]. Recruitment of Mis18 complex to the centromeres primes them for deposition of CENP-A by HJURP (Figure 1A). Depletion of any subunit of the Mis 18 complex, using RNAi, prevents CENP-A deposition, and results in chromosome segregation defects such as misaligned chromosomes and interphase micronuclei [106,111,112]. Mis18 $\alpha$ and Mis18 $\beta$ are proposed to form either a heterotetramer [113], or hexamer [114,115] through their C-terminal coiled-coil domains [113]. Mis18BP1 then binds to Mis18 $\alpha / \beta$ and the full complex localizes to centromeres through CENP-C-mediated binding to M18BP1 at anaphase onset [111] (Figure 1C). HJURP is recruited to centromeres by directly interacting with the C-terminal coiled-coil domains of Mis18 $\alpha / \beta$ [113]. Binding of HJURP is proposed to disrupt the Mis18 complex leading to removal of Mis18 $\alpha$ [113] and of M18BP1 [105], thereby restricting CENP-A deposition to a single event per cell cycle. Contrarily, recent work proposes that HJURP does not cause dissociation of the Mis18 complex and that HJURP is not dimerized in the process of CENP-A deposition [116], as previously suggested [117]. Deposition of CENP-A:H4 dimers into a homotypic octameric nucleosome is proposed to be achieved through two nearby Mis18:HJURP complexes depositing individual CENP-A:H4 dimers that are tetramerized into the same nucleosome [116]. 
A

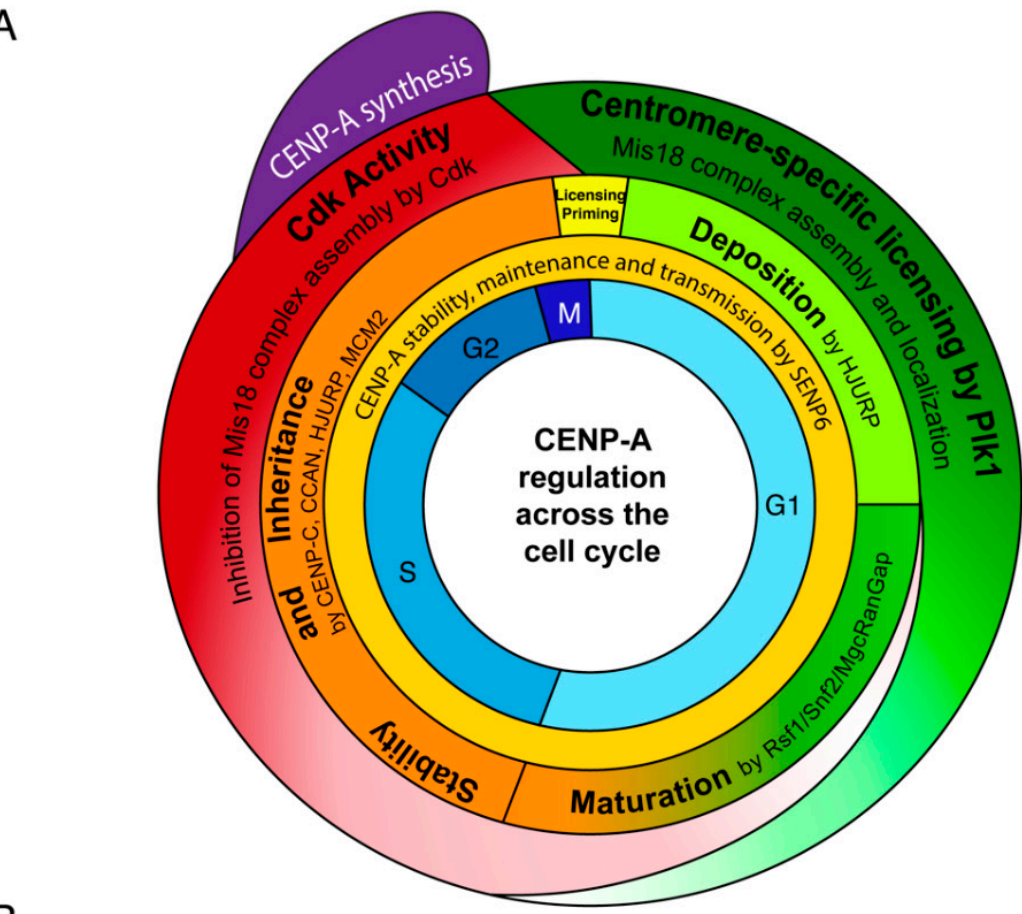

B
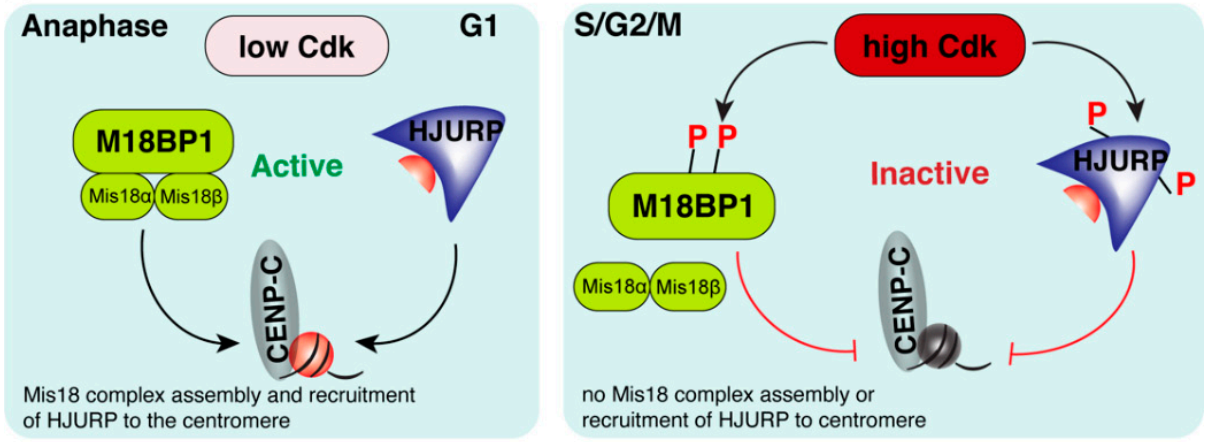

C

Anaphase

G1
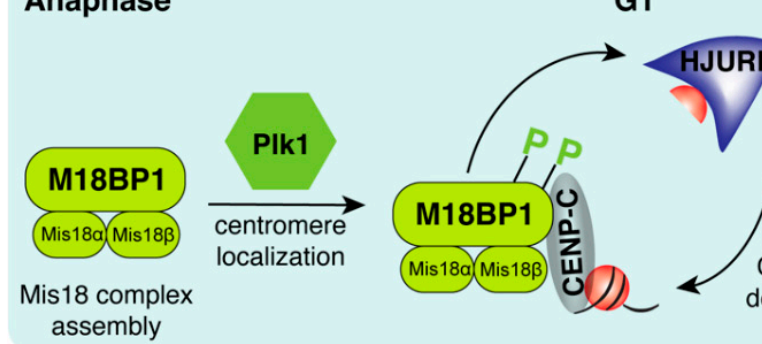

CENP-A P Cdk phosphorylation deposition P PIk1 phosphrylation

Figure 1. Centromere protein A (CENP-A) deposition and maintenance are cell-cycle dependent. (A) CENP-A synthesis, deposition and maturation occur in distinct cell cycle phases and are regulated by coordinated activity of deposition, maturation factors and cell cycle kinases. (B) Cyclin-dependent kinase (CDK) regulation of Mis18 complex assembly. Phosphorylation of M18BP1 and Holliday Junction Recognition Protein (HJURP) by CDK1/2 renders them inactive, inhibits assembly of the Mis18 complex, and prevents HJURP recruitment to centromeres, preventing CENP-A deposition. At anaphase, low CDK1/2 levels result in active M18BP1 and assembly of Mis18 complex, recruitment of active HJURP and deposition of new CENP-A at the next G1. (C) Phosphorylation of M18BP1 by Plk1 is required for the assembly of the Mis18 complex and its localization to G1 centromeres. Once localized at centromeres by binding to CENP-C, HJURP is recruited to centromeres by binding to the Mis18 complex, leading to the subsequent deposition of new CENP-A. 


\section{Global Regulation Restricts CENP-A Assembly to Early G1}

The restriction of CENP-A deposition to early G1 is achieved through global regulation by CDK1/2 activity that occurs during S, G2, and M phase until mitotic exit (Figure 1A,B). CDK1/2 kinases-mediated phosphorylation of two key CENP-A assembly factors, M18BP1 and HJURP, render both inactive, inhibits Mis18 complex assembly and prevents unscheduled centromeric chromatin assembly outside of the G1 phase [104,105] (Figure 1B). At anaphase onset, CDK activity dramatically drops, leading to dephosphorylation of sites within M18BP1 protein [104] (Figure 1A,B). In parallel, polo-like kinase 1 (Plk1)-mediated phosphorylation of Mis18 $\alpha$, Mis18 $\beta$, and M18BP1 proteins promotes their assembly into the Mis18 complex and its centromeric localization [110,115] (Figure 1C). Thus, Plk1 licenses centromeres for CENP-A deposition by providing a centromere-localization signal for the Mis18 complex. HJURP is subsequently recruited by binding to Mis $18 \alpha / \beta[113,118]$ leading to targeted deposition of new CENP-A at early G1 [100,102,103,110] (Figure 1C).

CENP-A loading at centromeres is mediated by factors that chaperone the loading process. The CENP-A pre-nucleosomal complex was identified in human cells to consist of CENP-A, HJURP, histone H4, NPM1 (nucleophosmin 1) [102,103] and RbAP48 [103]. HJURP, CENP-A's specific chaperone, binds directly to soluble CENP-A and is required for its chromatin assembly in human [102,103] and xenopus [111]. Depletion of HJURP from human cells [102,103] causes defects in CENP-A assembly $[102,103,119]$. Furthermore, as mentioned above, tethering HJURP to an ectopic non-centromeric locus is sufficient to induce incorporation of CENP-A into the chromatin at this site and leads to nucleation of a functional de novo kinetochore [31,32]. HJURP binds a single CENP-A-histone:H4 heterodimer [120] and is thought to achieve the assembly of homotypic octameric CENP-A nucleosomes via dimerization of HJURP through its C-terminal domain [117] or through two nearby Mis18:HJURP complexes, each depositing individual CENP-A:H4 dimers that are tetramerized into the same nucleosome [116].

\section{Maturation and Stability of Newly Deposited CENP-A}

In the second part of the G1 phase, newly deposited CENP-A goes through incorporation and stabilization processes. This is achieved by the remodeling and spacing factor (RSF) complex [121] and MgcRacGap [122] that interact transiently with centromeres to stabilize newly assembled CENP-A nucleosomes and generate mature centromeric chromatin (Figure 1A). When the cell transitions to S-phase, CDK1/2 activity levels increase, Mis18BP1 is phosphorylated, releases from centromeric chromatin, and CENP-A deposition is inhibited [104,123]. CENP-A synthesis increases in G2 [124,125] (Figure 1A), and newly synthetized CENP-A is bound by the chaperone HJURP in a pre-nucleosomal (non-chromatin associated) complex [102,103]. Increasing CDK1/2 activity inhibits both Mis18BP1 and HJURP (through a cyclin-interacting domain in HJURP) [104,105] and prevents premature CENP-A deposition at G2 phase of the cell cycle (Figure 1B).

The SUMO-protease SENP6, mentioned above, affects strongly not only the entire centromere and kinetochore, but also the assembly and maintenance of CENP-A [96,97]. Loss of SENP6 results in loss of old and newly deposited CENP-A [96], and both Mis18BP1 and Mis18 $\alpha$ are regulated by SENP6 [97]. CENP-A is lost from the centromere whether SENP6 is depleted in S, G2, or G1 phase [96]. Thus, SENP6 is continuously required throughout the cell cycle to prevent CENP-A from being removed from the centromere, to stabilize the centromere and kinetochore, and to ensure CENP-A chromatin transmission [96] (Figure 1A).

\section{CENP-A Inheritance at the Centromeric DNA Replication Fork Crossroad}

During centromeric DNA replication, chromatin-bound CENP-A is quantitatively redistributed to each daughter centromere $[37,100]$ and no new CENP-A deposition occurs until early G1. Thus, there is a temporal separation between replication of centromeric DNA and full reconstitution of centromeric chromatin. This raises an important question: how is the centromeric epigenetic mark maintained 
across the cell cycle, when it would be expected to be displaced by DNA replication and diluted at each centromere, as no new CENP-A is assembled until the next G1 [100]? Using CENP-A ChIP-sequencing and mapping onto centromere reference models for human $X$ chromosome [126] and for each autosome (incorporated into the HuRef genome hg38) [127,128], we recently identified the sequences bound by CENP-A in each of the human centromeres [12]. CENP-A is reproducibly localized to the same centromeric sequences before and after DNA replication. The DNA replication machinery not only replicates DNA but also maintains epigenetically defined centromere identity by mediating precise reassembly of centromere-bound CENP-A chromatin onto the exact same centromeric DNA sequences within the replicating daughter centromere [12] (Figure 2). As mentioned above, CENP-C and the CCAN complex it nucleates are essential for kinetochore assembly prior to mitosis and for ensuring faithful chromosome segregation [80,83,85,91-95]. Surprisingly, CENP-C and the CCAN complex are also essential during DNA replication for the retention of CENP-A at centromeres. Induced rapid degradation of endogenously tagged CENP-C AID/AID at early S-phase, results in a significant loss of CENP-A by G2 [12]. In addition, we find that CENP-A interacts robustly with MCM2 at late S phase, the time of centromeric DNA replication [12]. MCM2 is a core subunit of the DNA replicative helicase MCM2-7 complex that recycles old histones as the replication fork advances [129]. Chromatin assembly factor 1 (CAF1), required for de novo chromatin assembly following DNA replication [130], was also copurified with CENP-A in late-S-phase-derived chromatin. These results suggest that CENP-C and the CCAN complex function during centromeric DNA replication to tether CENP-A to the centromeric replication fork, thereby stabilizing CENP-A binding to MCM2 replicative helicase and CAF1 at the time of centromeric DNA replication [12] (Figure 2). At the chromosome arms, MCM2 recycles histone H3/H4 dimers together with the chaperone ASF1 [129,131]. Interestingly, HJURP can interact with MCM2 [129,132] and depletion of HJURP at early S phase results in significant loss of CENP-A from centromeres by G2, demonstrating that recycling of CENP-A:H4 dimers at the centromere by MCM2 requires HJURP as well [132], with HJURP at centromeres perhaps replacing the role of ASF1 at the chromosome arms. Taken together, a model emerges wherein the local CENP-C/CCAN-dependent retention of CENP-A, coupled with the coordinated actions of MCM2, HJURP and CAF1, enables precise reassembly of CENP-A into chromatin within each daughter centromere, thereby maintaining epigenetically defined centromere identity (Figure 2).

Even with retention of CENP-A at the same centromeric sequences, overall quantities of CENP-A are reduced by half, from 200 nucleosomes on average per centromere [37] to 100 nucleosome on average, and human cells undergo mitosis with only half the maximal CENP-A content loaded at centromeres $[98,100]$. Nucleosomes containing the histone variant H3.3 have been suggested to serve as "placeholders" during S phase in human [133], with subsequent removal in G1, allowing for new CENP-A deposition. A similar placeholder model has been shown to occur in fission yeast with $\mathrm{H} 3$ deposition at $\mathrm{S}$ phase at centromeres and subsequent removal in G2, when new CENP-A ${ }^{\text {Cnp1 is }}$ deposited [134]. 


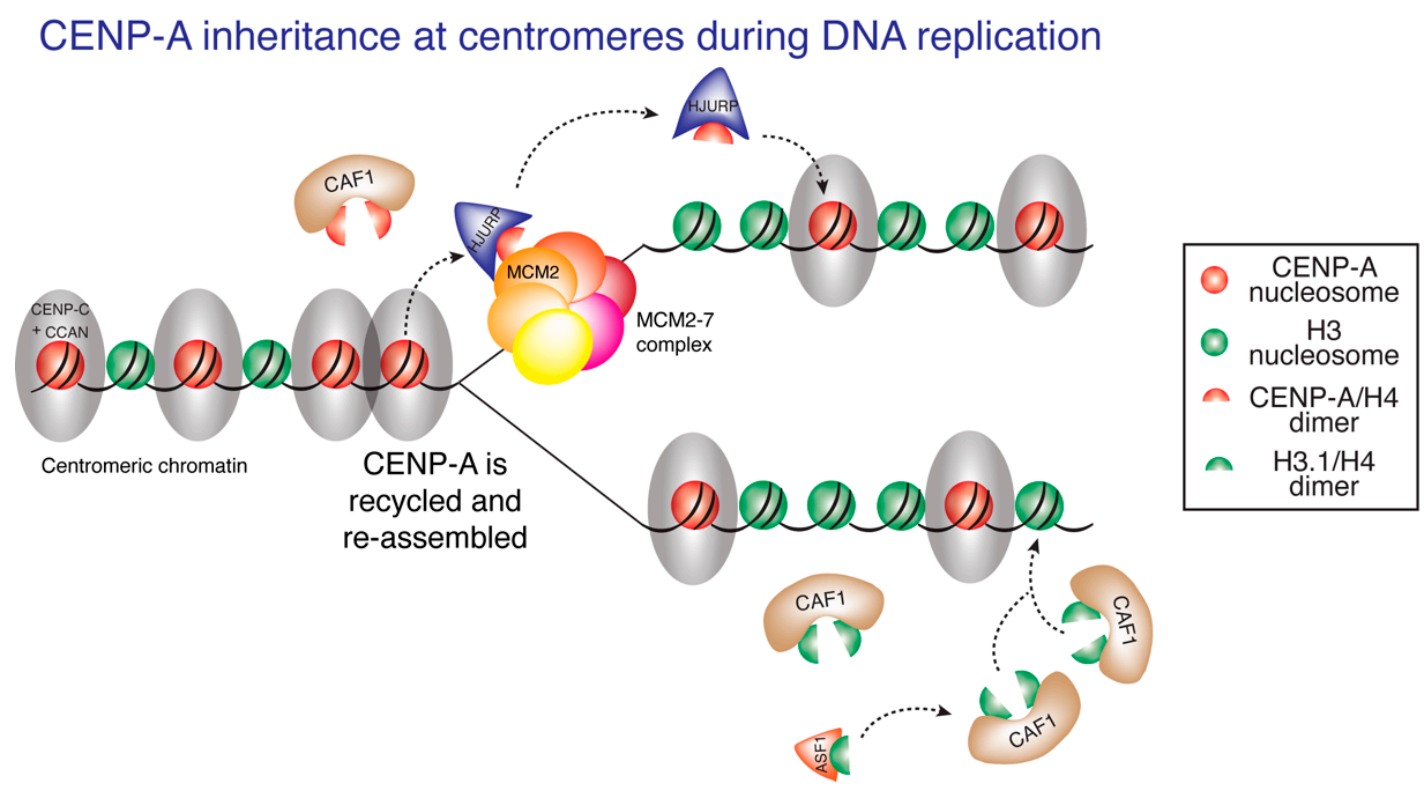

Figure 2. CENP-A inheritance during DNA replication. Presence of the constitutive centromereassociated network (CCAN) complex at centromeric chromatin tethers CENP-A in close proximity to the centromeric DNA replication fork and promotes stable interaction between CENP-A and MCM2. The coordinated action of MCM2, HJURP and CAF1 enables recycling of CENP-A:H4 dimers and their reassembly onto the daughter centromeres, preserving centromere identity.

\section{DNA Replication Ensures Centromere Specificity}

Previous studies have shown that besides assembly at centromeres, a proportion of CENP-A is assembled ectopically onto sites on the chromosome arms [12,14,37,48,135]. Artificially increasing CENP-A expression in human cells increases ectopic deposition at non-centromeric sites, primarily at transcriptionally active sites $[12,48]$, and is accompanied by chromosome segregation aberrations [48,136-138]. Therefore, long-term maintenance of centromere identity and function should involve limiting accumulation of non-centromeric CENP-A to ensure the formation of only one centromere per chromosome [12].

Although several E3 ligases have been identified that lead to degradation of endogenous CENP-A $^{\text {Cse4 }}\left[139\right.$ ] and of non-centromeric CENP-A ${ }^{\text {Cse4 }}$ in budding yeast [140-144], CENP-A ${ }^{\text {Cnp1 }}$ in fission yeast [145] and CENP-A ${ }^{C I D}$ in flies [146,147], almost nothing was known until recently about the pathways that degrade and limit accumulation of non-centromeric CENP-A in humans [123]. Using CENP-A chromatin immunoprecipitation and genome-wide mapping, we recently identified that DNA synthesis not only replicates DNA, but also functions to correct errors in CENP-A deposition by removing ectopic CENP-A from non-centromeric sites [12] (Figure 3A). Most ectopic sites of CENP-A deposition are found in early and mid-replicating regions. As DNA replication progresses, ectopic CENP-A is removed from the replicating chromatin (Figure 3B). In contrast, at the centromere, the same DNA replication machinery mediates the precise reassembly of centromere-bound CENP-A onto the same centromeric DNA sequences, in a coordinated action that requires MCM2 [12,132], HJURP [132], CENP-C and the CCAN complex it nucleates [12] (Figure 2). The concomitant removal of CENP-A from non-centromeric sites and retention of CENP-A at centromeric sites, both achieved during DNA replication, function to maintain epigenetically defined centromere identity, by ensuring that CENP-A is restricted to centromeres only and by preventing accumulation of ectopic CENP-A and acquisition of neocentromeres on the chromosome arms [12]. 


\section{A CENP-A removal from ectopic sites during DNA replication}

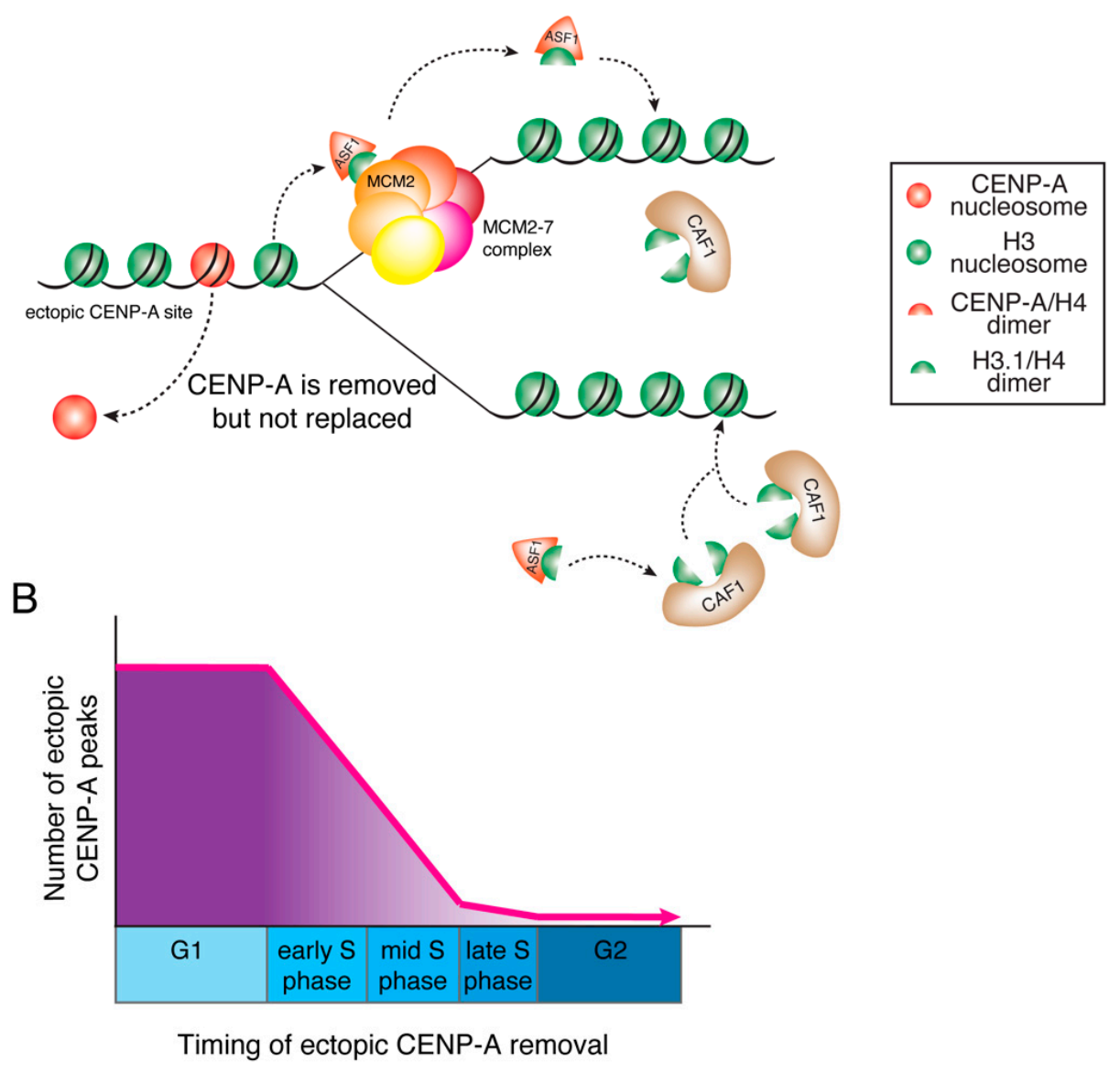

Figure 3. Ectopically loaded CENP-A is removed during DNA replication. (A) DNA replication corrects errors in CENP-A deposition by removing ectopic CENP-A from non-centromeric sites. As ectopic CENP-A is not tethered to the replication fork by the CCAN, it is removed from ectopic sites during DNA replication and diluted in the pool of available histones. CENP-A is replaced by histone H3.1:H4 dimers through the combined action of MCM2 and the chaperone ASF1. (B) Ectopic CENP-A is primarily found at early- and mid-replicating DNA regions and is removed as replication proceeds during $S$ phase. At the end of $S$ phase, nearly all CENP-A molecules have been removed from ectopic sites.

\section{Connecting CENP-A, Chromosomal Instability and Cancer}

Overexpression of CENP-A has been identified in 20 different cancer types, including liver, pancreatic, endometrial, breast, ovarian, colorectal, gastric, CNS and lung cancers and is considered a prognostic biomarker of metastatic ability, advanced disease state, poor outcome, and likelihood of relapse ([148-153] and Human Protein Atlas). As the defining epigenetic mark of the centromere serving as a keystone for downstream kinetochore assembly, CENP-A is inherently related to maintaining genomic integrity. As such, specific centromere inactivation of the $\mathrm{Y}$ chromosome, using CENP-A/histone $\mathrm{H} 3$ chimaera that cannot directly recruit CENP-C, leads to high levels of aberrant mitoses followed by similarly high levels of aneuploidy for the Y chromosome [154]. Remarkably, catastrophic numerical and structural chromosomal changes, including chromothripsis (the catastrophic shattering of a single or few chromosomes in a single event), can arise from a single cell division error [154-156], that can contribute to cancer development [157]. CENP-A overexpression in cancer may play a role in tumor formation and/or progression through increasing chromosome segregation errors. Indeed, overexpression of CENP-A results in chromosome segregation errors [137], providing a possible 
mechanism explaining the correlation of CENP-A overexpression with cancer invasiveness and poor prognosis seen in breast adenocarcinoma and lung squamous cell carcinoma $[148,158]$.

Chromosomal instability (CIN), a hallmark of cancer occurring in almost $90 \%$ of human tumors $[1,159,160]$, is defined as an increase in the rate of chromosome segregation errors over successive cell divisions, resulting in numerical and structural chromosomal abnormalities [5]. CIN contributes to cancer progression, aggressiveness and ability to evade cancer treatment $[5,161]$. By causing genomic rearrangements, CIN also contributes to gene expression changes that drive cancer progression [162,163]. CIN can be found early in tumor development and is therefore implicated in cancer initiation and disease progression $[2,4,164]$. CIN levels correlates positively with tumor stage, likelihood of relapse, prevalence of metastasis and resistance to treatment $[5,165]$.

Interestingly, CIN can originate from mitotic defects caused by lagging chromosomes failing to properly segregate in anaphase, primarily due to incorrect microtubule attachments to the kinetochore $[5,159,166]$. Such mitotic defects can result in aneuploidy or polyploidy, genomic rearrangements, micronuclei formation, or chromothripsis $[3,154,156,167,168]$. Levels of CENP-A expression have been shown recently to directly correlate with the number of chromosome segregation defects and incidence of micronuclei formation, linking CENP-A and CIN [137]. However, the complex relationship between CENP-A levels, CIN and gene expression changes in cancer development and/or progression is poorly understood.

\section{Ectopic Deposition of CENP-A and CIN}

The primary mechanism connecting CENP-A and CIN is the mislocalization of CENP-A-containing nucleosomes to ectopic positions on chromosome arms, away from the centromere $[12,14,48,135,137]$. Ectopic deposition of CENP-A has been shown to occur naturally in RPE-1 (chromosomally stable diploid retinal pigmented epithelial) cells [37] and accounts for $\sim 73 \%$ of total chromatin-bound CENP-A, measured using several quantitative fluorescence-based methods [37]. Using CENP-A ChIP-sequencing, $17 \%$ [48] to $25 \%$ [12] of CENP-A-bound DNAs are reported to be non-centromeric in HeLa (immortalized cervical cancer) cells expressing endogenous levels of CENP-A. Upon overexpression of CENP-A in HeLa cells ( $4-5 \times$ fold), non-centromeric CENP-A-bound DNAs increase to $~ 50 \%$ of total CENP-A-bound DNAs $[12,14,48]$. An increase in ectopic deposition upon CENP-A overexpression has been demonstrated in HeLa cells [12,48,137], DLD1 (colorectal adenocarcinoma) cells [12], RPE-1 cells [137] and SW480 (colorectal cancer) cells [135], using immunofluorescence, CENP-A ChIP-sequencing and CENP-A ChIP-qPCR. Most importantly, mislocalization of overexpressed CENP-A to the chromosome arms in HeLa and RPE-1 cells resulted in chromosome congression defects, lagging chromosomes, micronuclei formation and a delay in mitotic exit, directly linking CENP-A overexpression and ectopic CENP-A deposition with CIN [137]. This was associated with altered localization of CENP-C, CENP-T and Nuf2 and weakened native kinetochores [138] (Figure 4). 


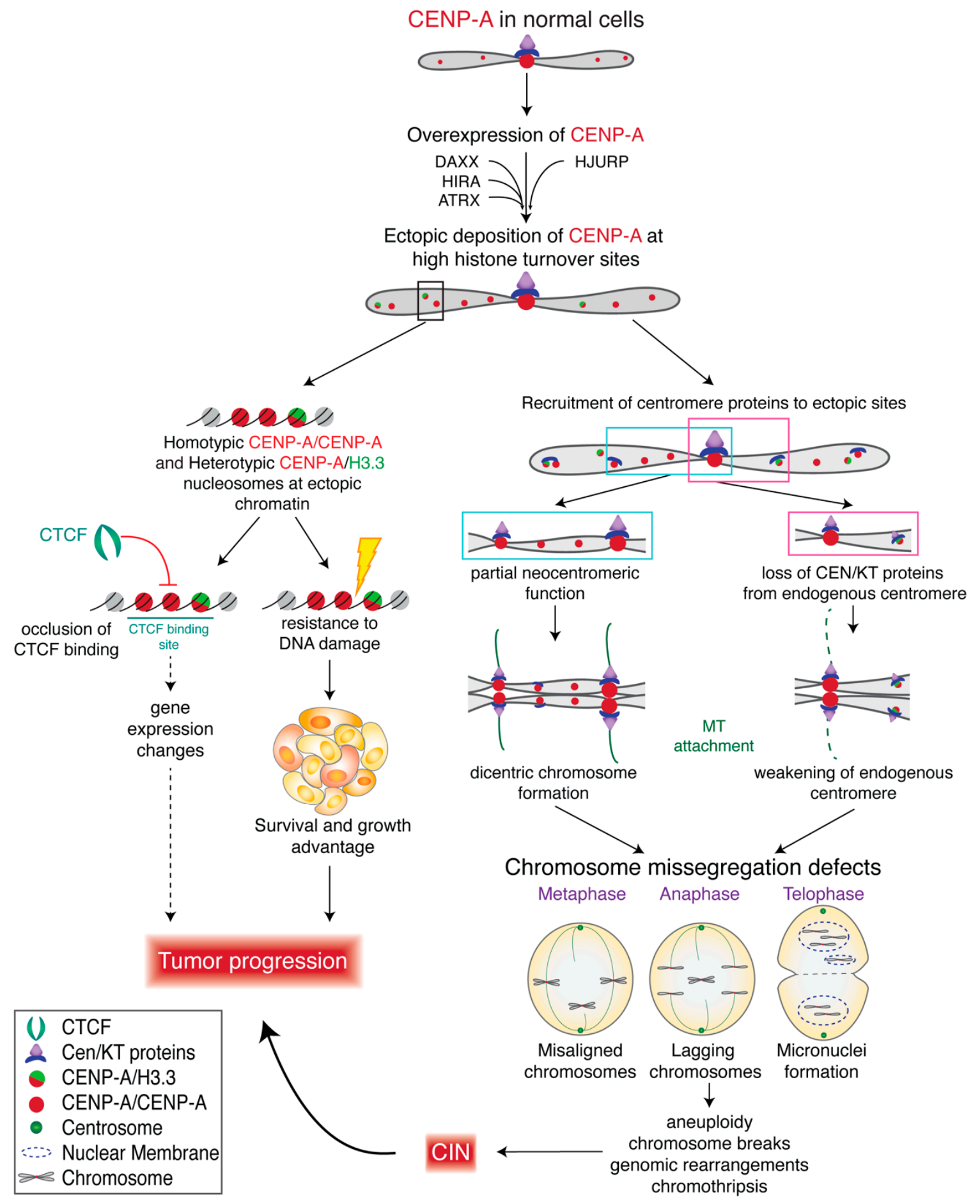

Figure 4. CENP-A overexpression in cancer cells contributes to CIN and tumor progression. Overexpression of CENP-A in cancer cells increases rates of CENP-A ectopic deposition at sites of high histone turnover. Ectopic CENP-A, consisting of homotypic or heterotypic particles, can occlude CCCTC-binding factor (CTCF) binding and regulatory elements which may contribute to gene expression changes that further affect tumor progression. CENP-A overexpression can also confer survival advantage to tumors by increasing resistance to DNA damage. CENP-A overexpression may recruit centromere and kinetochore $(\mathrm{CEN} / \mathrm{KT})$ proteins to ectopic CENP-A sites and can trigger formation of neocentromeres, while weakening endogenous centromeres and leading to chromosome segregation defects. 
HJURP, CENP-A's chaperone, deposits CENP-A at centromeres [102,103] at exit of mitosis [100,101], resulting in assembly of CENP-A into a homotypic octameric nucleosome with two molecules of CENP-A $[14,48,51,52,57]$. When overexpressed, CENP-A has been suggested to form, in addition to the homotypic nucleosome, a heterotypic octameric particle containing one molecule of CENP-A and one molecule of histone H3.3, that is deposited at ectopic sites by the histone H3.3 chaperone death domain-associated protein 6 (DAXX) $[48,137]$. While centromeric CENP-A particles were largely homotypic, those in chromosome arms were reported to be made up of both types of particles [48] (Figure 4). Importantly, DAXX is also upregulated in some cancer cell lines where CENP-A is upregulated [135], and both DAXX and HJURP have structurally similar histone binding domains [169]. Notably, siRNA-mediated depletion of DAXX in HeLa cells overexpressing CENP-A prevents ectopic deposition of CENP-A [48] and suppresses chromosome segregation defects [137], suggesting a role for DAXX in ectopic CENP-A deposition and linking CENP-A expression levels to CIN. Interestingly, fly CENP-A ${ }^{\mathrm{CID}}$ has been shown to use a separate loading mechanisms for its incorporation into centromeric and ectopic sites; CAL1 is required for loading at the centromere, while the NuRD

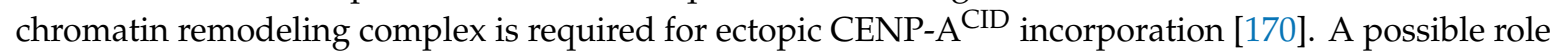
in depositing CENP-A at non-centromeric sites was also suggested for ATRX [135] and HIRA [171].

Studies from Lacoste and colleagues [48] and from us [12,14] have used HeLa cells exhibiting similar levels of CENP-A overexpression ( $4.5 \times$ fold) and found similar levels ( $50 \%)$ of CENP-A mislocalization. Nevertheless, our data shows that the overwhelming majority of human CENP-A chromatin particles, in these overexpression conditions, are octameric nucleosomes containing two molecules of CENP-A at all cell cycle points, with heterotypic CENP-A/histone H3-containing nucleosomes comprising at most $2 \%$ of total CENP-A-containing chromatin [14]. Thus, the overwhelming majority of ectopic CENP-A-containing chromatin is assembled with homotypic CENP-A nucleosomes in our CENP-A overexpressing HeLa cell line (Figure 4), suggesting that HJURP might still play a significant role in ectopic deposition of CENP-A. Importantly, HJURP is also elevated in certain cancers (Figure 5B), including breast and pancreatic cancers, where upregulation of HJURP was found to correlate with decreased survival [172], and HJURP expression level serves as an unfavorable prognostic marker in melanoma, as well as pancreatic, liver, and lung cancers ([173,174], and The Cancer Genome Atlas (TCGA) data). 


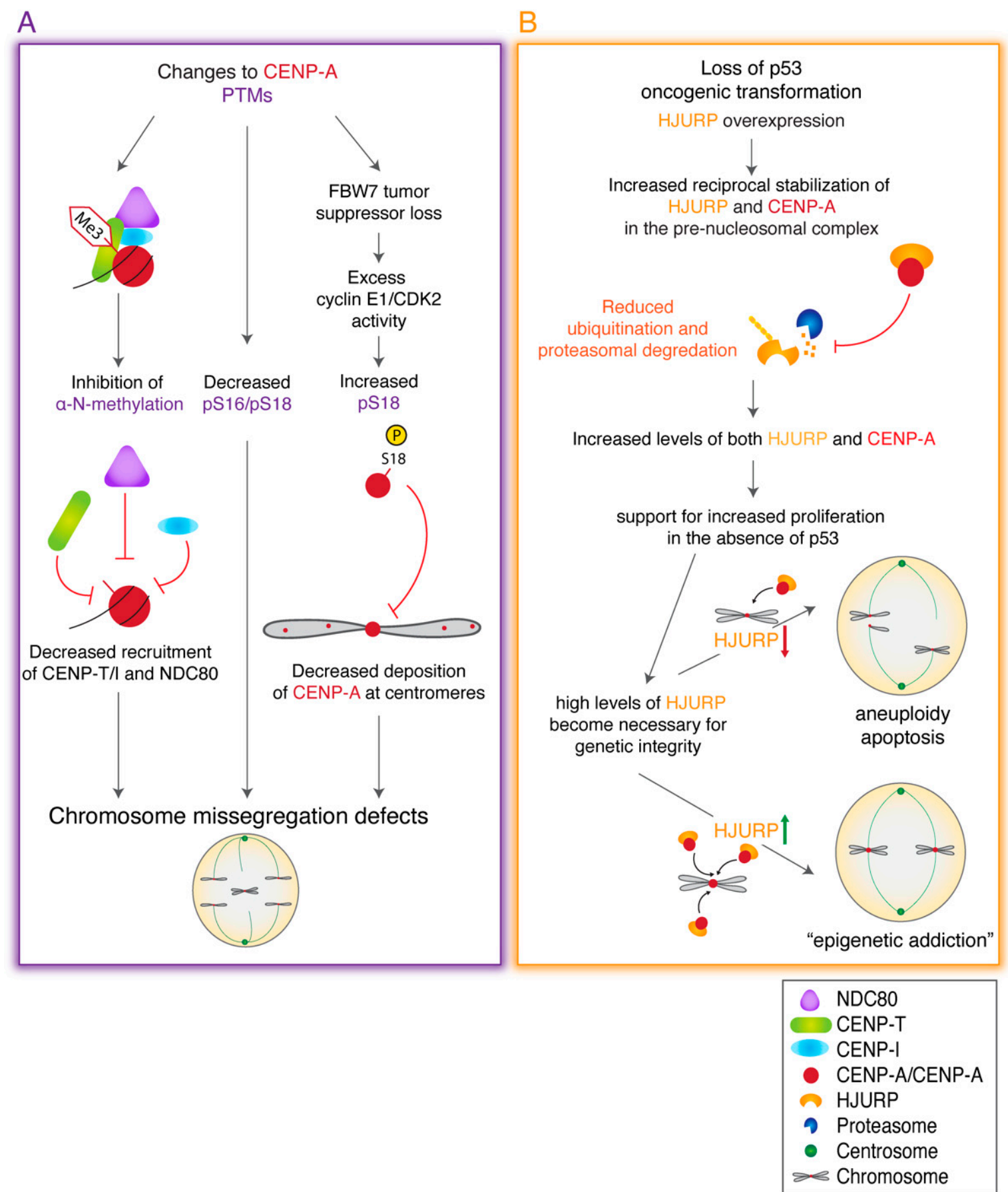

Figure 5. Alterations to CENP-A PTMs and/or to HJURP expression levels contribute to CIN and tumor progression. (A) Alterations to CENP-A posttranslational modifications (PTMs) can reduce recruitment of CCAN and kinetochore components, reduce CENP-A deposition at centromeres, and lead to chromosome segregation defects. (B) HJURP overexpression stabilizes CENP-A in the pre-nucleosomal complex and CENP-A protects HJURP from degradation. In p53 null cancers, upregulated HJURP levels become critical for maintaining centromere integrity and preventing apoptosis as p53-mediated DNA checkpoints are lost, leading to HJURP epigenetic addiction that contributes to tumor survival and progression.

\section{CENP-A Misregulation and Gene Expression}

Ectopic deposition of CENP-A may have consequences beyond competing with and weakening native centromeres. CENP-A nucleosomes confer unique properties to chromatin where they are 
deposited, resulting in DNA unwinding of the entry/exit sites of the nucleosome $[14,48,57]$ and producing a more globally condensed chromatin state [58]. Deposition of CENP-A into ectopic sites might therefore affect DNA accessibility, chromatin secondary structure, and gene expression (Figure 4). Consistent with this idea, CENP-A molecules deposited on chromosome arms are found primarily in sites of high histone turnover, such as active transcription sites, regulatory regions, and sites of CTCF binding $[12,48,135]$, leading to occlusion of CTCF binding [48]. Occlusion of CTCF binding has been shown in many cancer types, is associated with aberrant gene expression and is thought to contribute to tumorigenicity [175-178]. Surprisingly, no significant gene expression changes were identified in HeLa cells showing ectopic CENP-A mislocalization and occlusion of CTCF binding sites [48]. It remains to be established whether gene expression is affected at higher levels of CENP-A overexpression and/or in different types of cancer.

In SW480 colorectal cancer cells CENP-A hotspots accumulate at subtelomeric chromosomal locations, including at the 8q24/Myc region long-associated with genomic instability, and with CENP-C recruitment to this location. CENP-A deposition at this locus occurs in early stage colorectal tumors $[135,171]$ and is correlated with amplification and overexpression of the MYC gene within that locus [171].

Lastly, overexpression of CENP-A alone, regardless of its deposition mechanics, appears to have some effect on gene expression dynamics. Hepatocellular carcinoma cells overexpressing CENP-A exhibit elevated expression of p53 inhibitor MDM2 and anti-apoptotic Bcl-2, decreased expression of pro-apoptotic Bax and modulate numerous cell cycle regulators [179]. Moreover, analyses of gene expression data from numerous primary cancer cell lines and patient clinical samples have identified 14 centromere and kinetochore assembly genes that are consistently overexpressed in human cancers [158]. These 14 genes include regulators of CENP-A nucleosome assembly (HJURP, Mis18 $\beta$ ), centromere proteins (CENP-A, -K, -L, -M, -N, -U, -W), and kinetochore proteins (NDC80, SPC24, SPC25, NUF2, ZWINT), highlighting the role of centromere and kinetochore gene misexpression in cancer progression [158]. Thirty-nine percent of the 18 cancer types analyzed showed significant positive correlation between the $14 \mathrm{CEN} / \mathrm{KT}$ elevated genes signature and genome instability (measured by copy-number alterations (CNA) and mutation frequency), including breast, lung and stomach adenocarcinomas (ADC) and low-grade brain gliomas. Moreover, this $14 \mathrm{CEN} / \mathrm{KT}$ elevated genes signature also correlated with poor patient survival for breast and lung cancers [158].

\section{Perturbations in CENP-A Posttranslational Modifications are Linked to Cancer}

CENP-A function is also regulated by posttranslational modifications to the CENP-A histone itself. Several sites of posttranslational modification have been identified for CENP-A, including $\alpha$-amino trimethylation [180], Ser7 phosphorylation [181,182], Ser16/18 phosphorylation [161, 183], Ser68 phosphorylation [184,185], Lys124 ubiquitination [185-188], Lys124 acetylation [50,189], and Lys124 monomethylation [189], some of which are emerging as important regulators of CENP-A deposition and function within the centromere [reviewed at Srivastava and Foltz [190]].

Several perturbations in CENP-A posttranslational modifications have been linked to chromosome segregation defects and cancer (Figure 5A). Inhibition of CENP-A $\alpha$-amino trimethylation causes a reduction in CENP-T and CENP-I at the centromere, leading to lagging chromosomes [180]. Furthermore, CENP-A is known to be phosphorylated at two highly conserved residues, Ser16 and Ser18 (located within the amino terminal tail of CENP-A), prior to its deposition and in the CENP-A nucleosome [183]. Loss of phosphorylation at Ser16/18 has been shown to lead to chromosome missegregation [183]. In contrast, hyper-phosphorylation at Ser18 also lead to chromosome missegregation and severe CIN phenotype and is linked to the loss of FBW7 [161], an E3 ubiquitin ligase and one of the most frequently lost tumor suppressors in human cancers [191]. CENP-A Ser18 is a substrate for cyclinE1/CDK2 phosphorylation and is cell cycle regulated [161]. Hyperphosphorylation of CENP-A Ser18 by cyclinE1/CDK2 reduced its centromeric localization, increased levels of lagging chromosomes, chromosomal bridges, and micronuclei formation, and even 
promoted anchorage-independent growth and xenograft tumor formation [161]. Thus, cyclin E1/CDK2 activation coupled with tumor suppressor FBW7 loss can promote CIN and tumor progression through reducing CENP-A's centromeric localization, leading to centromere dysfunction (Figure 5A).

\section{CENP-A Overexpression May Be Indispensable for Cancer Progression}

Typically, CENP-A and HJURP protein levels are tightly co-regulated in accordance with cell cycle progression $[103,123]$ and CENPA and HJURP genes have similar CDE/CHR binding motifs in their promoters, suggesting that they are both negatively regulated indirectly by $\mathrm{p} 53$ through the DREAM complex [138] and/or through FOXM1 [192,193]. Consistent with that, both CENP-A and HJURP are transcriptionally up-regulated in p53-null human tumors [138]. In addition, CENP-A and HJURP have reciprocal stabilizing effects on each other. Specifically, siRNA-mediated depletion of CENP-A promote proteasome-dependent degradation of HJURP [138] and HJURP stabilizes CENP-A [102,103]. In flies, CAL1 mediates CENP-A ${ }^{\text {CID }}$ ubiquitylation by CUL3/RDX that stabilizes CENP-A CID and CAL1 [194]. When expression of either CENP-A or HJURP is reduced in non-cancerous cells, deposition of new CENP-A at exit of mitosis is diminished, causing loss of centromere identity and increased segregation errors and micronuclei $[26,41,102,103]$. Additionally, degradation of HJURP in early $S$ phase impairs retention of CENP-A at centromeres throughout $S$ phase [132]. All of this demonstrates that co-regulation of CENP-A and HJURP is important for maintaining a fine balance that preserves centromere identity.

As discussed previously, CENP-A is upregulated in many cancers and correlates with multiple markers of poor prognosis $[148,158]$. Like CENP-A, HJURP is overexpressed in certain cancers, including breast, liver, pancreatic, lung and melanoma cancers (The Human Protein Atlas), where upregulation of HJURP correlates with decreased survival [172]. Furthermore, partial depletion of CENP-A by about $50-70 \%$ in cancer cells overexpressing CENP-A reduces proliferation and cell cycle progression, colony formation, migration and invasiveness, and increases rates of apoptosis [179,195]. Similarly, in cancer cells overexpressing HJURP, 80\% depletion of HJURP using siRNA [196], or complete knockout of HJURP using CRISPR/Cas9 [138], induces cell cycle arrest and apoptosis, recapitulating the phenotype of CENP-A depletion in cancer cells. Though HJURP loss in wild-type cells causes cell cycle arrest, in p53-null transformed or cancer cells, HJURP loss leads to aneuploidy and elevated rates of apoptosis [138].

Interestingly, CENP-A and HJURP are both elevated following p53 loss and oncogenic transformation in what is proposed to be an "epigenetic addiction", where the transformed cells require elevated HJURP for growth and survival [138] (Figure 5B). In this model, HJURP and CENP-A levels are increased upon p53 loss and increase further following oncogenic transformation. In cells with p53, depletion of HJURP causes slow depletion of CENP-A at centromeres that can be sensed by p53 resulting in cell cycle arrest and maintenance of genome integrity. In cells lacking p53, HJURP depletion results in rapid CENP-A loss at centromeres, as the cells divide quickly. However, the loss of p53 prevents sensing of CENP-A loss, leading to severe centromere dysfunction, aneuploidy and apoptosis [138]. Together, these data highlight that overexpression of CENP-A and HJURP is essential for maintaining centromere identity and promoting survival in cancer cells, particularly as loss of p53 and cell cycle checkpoints allow rapid cell cycle progression without sensing of genome integrity. Cancer cells become "addicted" and require the sufficient expression of CENP-A and HJURP to ensure centromere identity is maintained and chromosome segregation is achieved/protected in the face of widespread genomic instability (Figure 5B).

In summary, the roles of CENP-A in cancer progression are multifaceted and complex. CENP-A overexpression, which is commonly observed in various cancers, can increase the rates of ectopic deposition of CENP-A through the collaborative efforts of multiple histone chaperones. Subsequently, sites of ectopic CENP-A may acquire partial neocentromeric function, weakening endogenous centromeres and contributing to increased occurrence of CIN. Alteration to posttranslational modifications (PTMs) of CENP-A in cancer reduce centromeric CENP-A deposition 
and recruitment of CCAN and kinetochore proteins, further destabilizing the centromere and favoring CIN. Ectopic CENP-A can also occlude binding of CTCF, a regulator of gene expression. Additionally, overexpression of CENP-A confers resistance to DNA damage across the genome [48], which could provide a survival advantage to tumors. CENP-A overexpression can also be accompanied by overexpression of its primary chaperone, HJURP, which increases the available pool of CENP-A for deposition at centromeres and possibly at ectopic sites. p53 loss, a key step in oncogenic transition, leads to overexpression of both CENP-A and HJURP and they become indispensable for maintaining centromere identity. Although currently unexplored, CENP-A is a potential target for modulating CIN as a therapeutic strategy in cancers. Targeting overall levels of CENP-A or perhaps ectopically loaded CENP-A specifically may provide a therapeutic benefit for cancers overexpressing CENP-A.

Author Contributions: M.A.M.: Writing-original draft; Y.N.-A.: Writing-original draft, Writing-review \& editing. All authors have read and agreed to the published version of the manuscript.

Funding: Y.N.-A. receives salary support from the University of Pittsburgh Hillman Cancer Center. This project was supported in part by the Hillman Fellows for Innovative Cancer Research Program funded by the Henry L. Hillman Foundation.

Acknowledgments: Many important contributions could not be cited due to space constraints, and we apologize to our colleagues for any relevant exclusion. We thank Ofer Shoshani, Lior Lumerman and Marlene Taja-Moreno for critical reading and suggestions.

Conflicts of Interest: The author declares no conflict of interest.

\section{References}

1. Carter, S.L.; Cibulskis, K.; Helman, E.; McKenna, A.; Shen, H.; Zack, T.; Laird, P.W.; Onofrio, R.C.; Winckler, W.; Weir, B.A.; et al. Absolute quantification of somatic DNA alterations in human cancer. Nat. Biotechnol. 2012, 30, 413-421. [CrossRef] [PubMed]

2. Lengauer, C.; Kinzler, K.W.; Vogelstein, B. Genetic instabilities in human cancers. Nature 1998, 396, 643-649. [CrossRef] [PubMed]

3. Funk, L.C.; Zasadil, L.M.; Weaver, B.A. Living in CIN: Mitotic Infidelity and Its Consequences for Tumor Promotion and Suppression. Dev. Cell 2016, 39, 638-652. [CrossRef] [PubMed]

4. Rajagopalan, H.; Lengauer, C. Aneuploidy and cancer. Nature 2004, 432, 338-341. [CrossRef]

5. Bakhoum, S.F.; Cantley, L.C. The Multifaceted Role of Chromosomal Instability in Cancer and Its Microenvironment. Cell 2018, 174, 1347-1360. [CrossRef]

6. Bolhaqueiro, A.C.F.; Ponsioen, B.; Bakker, B.; Klaasen, S.J.; Kucukkose, E.; van Jaarsveld, R.H.; Vivie, J.; Verlaan-Klink, I.; Hami, N.; Spierings, D.C.J.; et al. Ongoing chromosomal instability and karyotype evolution in human colorectal cancer organoids. Nat. Genet. 2019, 51, 824-834. [CrossRef]

7. Henikoff, S.; Ahmad, K.; Malik, H.S. The centromere paradox: Stable inheritance with rapidly evolving DNA. Science 2001, 293, 1098-1102. [CrossRef]

8. Cleveland, D.W.; Mao, Y.; Sullivan, K.F. Centromeres and kinetochores: From epigenetics to mitotic checkpoint signaling. Cell 2003, 112, 407-421. [CrossRef]

9. Manuelidis, L.; Wu, J.C. Homology between human and simian repeated DNA. Nature 1978, $276,92-94$. [CrossRef]

10. Willard, H.F. Chromosome-specific organization of human $\alpha$ satellite DNA. Am. J. Hum. Genet. 1985, 37, 524-532.

11. Alexandrov, I.; Kazakov, A.; Tumeneva, I.; Shepelev, V.; Yurov, Y. $\alpha$-satellite DNA of primates: Old and new families. Chromosoma 2001, 110, 253-266. [CrossRef] [PubMed]

12. Nechemia-Arbely, Y.; Miga, K.H.; Shoshani, O.; Aslanian, A.; McMahon, M.A.; Lee, A.Y.; Fachinetti, D.; Yates, J.R.; Ren, B.; Cleveland, D.W. DNA replication acts as an error correction mechanism to maintain centromere identity by restricting CENP-A to centromeres. Nat. Cell Biol. 2019, 21, 743-754. [CrossRef] [PubMed]

13. Willard, H.F.; Waye, J.S. Chromosome-specific subsets of human $\alpha$ satellite DNA: Analysis of sequence divergence within and between chromosomal subsets and evidence for an ancestral pentameric repeat. J. Mol. Evol. 1987, 25, 207-214. [CrossRef] [PubMed] 
14. Nechemia-Arbely, Y.; Fachinetti, D.; Miga, K.H.; Sekulic, N.; Soni, G.V.; Kim, D.H.; Wong, A.K.; Lee, A.Y.; Nguyen, K.; Dekker, C.; et al. Human centromeric CENP-A chromatin is a homotypic, octameric nucleosome at all cell cycle points. J. Cell Biol. 2017, 216, 607-621. [CrossRef]

15. Hayden, K.E.; Strome, E.D.; Merrett, S.L.; Lee, H.R.; Rudd, M.K.; Willard, H.F. Sequences associated with centromere competency in the human genome. Mol. Cell Biol. 2013, 33, 763-772. [CrossRef]

16. Miga, K.H. Centromeric Satellite DNAs: Hidden Sequence Variation in the Human Population. Genes Basel 2019, 10, 352. [CrossRef]

17. Stimpson, K.M.; Sullivan, B.A. Epigenomics of centromere assembly and function. Curr. Opin. Cell Biol. 2010, 22, 772-780. [CrossRef]

18. Marshall, O.J.; Chueh, A.C.; Wong, L.H.; Choo, K.H. Neocentromeres: New insights into centromere structure, disease development, and karyotype evolution. Am. J. Hum. Genet. 2008, 82, 261-282. [CrossRef]

19. Amor, D.J.; Bentley, K.; Ryan, J.; Perry, J.; Wong, L.; Slater, H.; Choo, K.H. Human centromere repositioning "in progress". Proc. Natl. Acad. Sci. USA 2004, 101, 6542-6547. [CrossRef]

20. Smith, M.M. Centromeres and variant histones: What, where, when and why? Curr. Opin. Cell Biol. 2002, 14, 279-285. [CrossRef]

21. Earnshaw, W.C.; Rothfield, N. Identification of a family of human centromere proteins using autoimmune sera from patients with scleroderma. Chromosoma 1985, 91, 313-321. [CrossRef] [PubMed]

22. Palmer, D.K.; O’Day, K.; Wener, M.H.; Andrews, B.S.; Margolis, R.L. A 17-kD centromere protein (CENP-A) copurifies with nucleosome core particles and with histones. J. Cell Biol. 1987, 104, 805-815. [CrossRef] [PubMed]

23. Fachinetti, D.; Folco, H.D.; Nechemia-Arbely, Y.; Valente, L.P.; Nguyen, K.; Wong, A.J.; Zhu, Q.; Holland, A.J.; Desai, A.; Jansen, L.E.; et al. A two-step mechanism for epigenetic specification of centromere identity and function. Nat. Cell Biol. 2013, 15, 1056-1066. [CrossRef] [PubMed]

24. Howman, E.V.; Fowler, K.J.; Newson, A.J.; Redward, S.; MacDonald, A.C.; Kalitsis, P.; Choo, K.H. Early disruption of centromeric chromatin organization in centromere protein A (Cenpa) null mice. Proc. Natl. Acad. Sci. USA 2000, 97, 1148-1153. [CrossRef] [PubMed]

25. Gemble, S.; Simon, A.; Pennetier, C.; Dumont, M.; Herve, S.; Meitinger, F.; Oegema, K.; Rodriguez, R.; Almouzni, G.; Fachinetti, D.; et al. Centromere Dysfunction Compromises Mitotic Spindle Pole Integrity. Curr. Biol. 2019, 29, 3072-3080. [CrossRef]

26. Regnier, V.; Vagnarelli, P.; Fukagawa, T.; Zerjal, T.; Burns, E.; Trouche, D.; Earnshaw, W.; Brown, W. CENP-A is required for accurate chromosome segregation and sustained kinetochore association of BubR1. Mol. Cell Biol. 2005, 25, 3967-3981. [CrossRef]

27. Ho, K.H.; Tsuchiya, D.; Oliger, A.C.; Lacefield, S. Localization and function of budding yeast CENP-A depends upon kinetochore protein interactions and is independent of canonical centromere sequence. Cell Rep. 2014, 9, 2027-2033. [CrossRef]

28. Mendiburo, M.J.; Padeken, J.; Fulop, S.; Schepers, A.; Heun, P. Drosophila CENH3 is sufficient for centromere formation. Science 2011, 334, 686-690. [CrossRef]

29. Olszak, A.M.; van Essen, D.; Pereira, A.J.; Diehl, S.; Manke, T.; Maiato, H.; Saccani, S.; Heun, P. Heterochromatin boundaries are hotspots for de novo kinetochore formation. Nat. Cell Biol. 2011, 13, 799-808. [CrossRef]

30. Palladino, J.; Chavan, A.; Sposato, A.; Mason, T.D.; Mellone, B.G. Targeted De Novo Centromere Formation in Drosophila Reveals Plasticity and Maintenance Potential of CENP-A Chromatin. Dev. Cell 2020, 52, 379-394. [CrossRef]

31. Barnhart, M.C.; Kuich, P.H.; Stellfox, M.E.; Ward, J.A.; Bassett, E.A.; Black, B.E.; Foltz, D.R. HJURP is a CENP-A chromatin assembly factor sufficient to form a functional de novo kinetochore. J. Cell Biol. 2011, 194, 229-243. [CrossRef] [PubMed]

32. Logsdon, G.A.; Gambogi, C.W.; Liskovykh, M.A.; Barrey, E.J.; Larionov, V.; Miga, K.H.; Heun, P.; Black, B.E. Human Artificial Chromosomes that Bypass Centromeric DNA. Cell 2019, 178, 624-639. [CrossRef] [PubMed]

33. Ohzeki, J.-I.; Nakano, M.; Okada, T.; Masumoto, H. CENP-B box is required for de novo centromere chromatin assembly on human alphoid DNA. J. Cell Biol. 2002, 159, 765-775. [CrossRef] [PubMed]

34. Schueler, M.G.; Higgins, A.W.; Rudd, M.K.; Gustashaw, K.; Willard, H.F. Genomic and Genetic Definition of a Functional Human Centromere. Science 2001, 294, 109-115. [CrossRef] [PubMed] 
35. Okada, T.; Ohzeki, J.-I.; Nakano, M.; Yoda, K.; Brinkley, W.R.; Larionov, V.; Masumoto, H. CENP-B Controls Centromere Formation Depending on the Chromatin Context. Cell 2007, 131, 1287-1300. [CrossRef]

36. Gambogi, C.W.; Dawicki-McKenna, J.M.; Logsdon, G.A.; Black, B.E. The unique kind of human artificial chromosome: Bypassing the requirement for repetitive centromere DNA. Exp. Cell Res. 2020, 391, 111978. [CrossRef]

37. Bodor, D.L.; Mata, J.F.; Sergeev, M.; David, A.F.; Salimian, K.J.; Panchenko, T.; Cleveland, D.W.; Black, B.E.; Shah, J.V.; Jansen, L.E. The quantitative architecture of centromeric chromatin. eLife 2014, 3, e02137. [CrossRef]

38. Blower, M.D.; Sullivan, B.A.; Karpen, G.H. Conserved organization of centromeric chromatin in flies and humans. Dev. Cell 2002, 2, 319-330. [CrossRef]

39. Sullivan, B.A.; Karpen, G.H. Centromeric chromatin exhibits a histone modification pattern that is distinct from both euchromatin and heterochromatin. Nat. Struct. Mol. Biol. 2004, 11, 1076-1083. [CrossRef]

40. Black, B.E.; Cleveland, D.W. Epigenetic centromere propagation and the nature of CENP-A nucleosomes. Cell 2011, 144, 471-479. [CrossRef]

41. Black, B.E.; Brock, M.A.; Bedard, S.; Woods, V.L., Jr.; Cleveland, D.W. An epigenetic mark generated by the incorporation of CENP-A into centromeric nucleosomes. Proc. Natl. Acad. Sci. USA 2007, 104, 5008-5013. [CrossRef] [PubMed]

42. Falk, S.J.; Lee, J.; Sekulic, N.; Sennett, M.A.; Lee, T.H.; Black, B.E. CENP-C directs a structural transition of CENP-A nucleosomes mainly through sliding of DNA gyres. Nat. Struct. Mol. Biol. 2016, 23, 204-208. [CrossRef] [PubMed]

43. Tachiwana, H.; Kagawa, W.; Shiga, T.; Osakabe, A.; Miya, Y.; Saito, K.; Hayashi-Takanaka, Y.; Oda, T.; Sato, M.; Park, S.Y.; et al. Crystal structure of the human centromeric nucleosome containing CENP-A. Nature 2011, 476, 232-235. [CrossRef] [PubMed]

44. Dalal, Y.; Wang, H.; Lindsay, S.; Henikoff, S. Tetrameric structure of centromeric nucleosomes in interphase Drosophila cells. PLoS Biol. 2007, 5, e218. [CrossRef] [PubMed]

45. Dimitriadis, E.K.; Weber, C.; Gill, R.K.; Diekmann, S.; Dalal, Y. Tetrameric organization of vertebrate centromeric nucleosomes. Proc. Natl. Acad. Sci. USA 2010, 107, 20317-20322. [CrossRef]

46. Furuyama, T.; Henikoff, S. Centromeric nucleosomes induce positive DNA supercoils. Cell 2009, 138, 104-113. [CrossRef]

47. Williams, J.S.; Hayashi, T.; Yanagida, M.; Russell, P. Fission yeast Scm3 mediates stable assembly of Cnp1/CENP-A into centromeric chromatin. Mol. Cell 2009, 33, 287-298. [CrossRef]

48. Lacoste, N.; Woolfe, A.; Tachiwana, H.; Garea, A.V.; Barth, T.; Cantaloube, S.; Kurumizaka, H.; Imhof, A.; Almouzni, G. Mislocalization of the centromeric histone variant CenH3/CENP-A in human cells depends on the chaperone DAXX. Mol. Cell 2014, 53, 631-644. [CrossRef]

49. Arimura, Y.; Shirayama, K.; Horikoshi, N.; Fujita, R.; Taguchi, H.; Kagawa, W.; Fukagawa, T.; Almouzni, G.; Kurumizaka, H. Crystal structure and stable property of the cancer-associated heterotypic nucleosome containing CENP-A and H3.3. Sci. Rep. 2014, 4, 7115. [CrossRef]

50. Bui, M.; Dimitriadis, E.K.; Hoischen, C.; An, E.; Quenet, D.; Giebe, S.; Nita-Lazar, A.; Diekmann, S.; Dalal, Y. Cell-cycle-dependent structural transitions in the human CENP-A nucleosome in vivo. Cell 2012, 150, 317-326. [CrossRef]

51. Padeganeh, A.; Ryan, J.; Boisvert, J.; Ladouceur, A.M.; Dorn, J.F.; Maddox, P.S. Octameric CENP-A nucleosomes are present at human centromeres throughout the cell cycle. Curr. Biol. 2013, 23, 764-769. [CrossRef]

52. Miell, M.D.; Fuller, C.J.; Guse, A.; Barysz, H.M.; Downes, A.; Owen-Hughes, T.; Rappsilber, J.; Straight, A.F.; Allshire, R.C. CENP-A confers a reduction in height on octameric nucleosomes. Nat. Struct. Mol. Biol. 2013, 20, 763-765. [CrossRef]

53. Sekulic, N.; Bassett, E.A.; Rogers, D.J.; Black, B.E. The structure of (CENP-A-H4) (2) reveals physical features that mark centromeres. Nature 2010, 467, 347-351. [CrossRef]

54. Boopathi, R.; Danev, R.; Khoshouei, M.; Kale, S.; Nahata, S.; Ramos, L.; Angelov, D.; Dimitrov, S.; Hamiche, A.; Petosa, C.; et al. Phase-plate cryo-EM structure of the Widom 601 CENP-A nucleosome core particle reveals differential flexibility of the DNA ends. Nucleic Acids Res. 2020, 48, 5735-5748. [CrossRef]

55. Roulland, Y.; Ouararhni, K.; Naidenov, M.; Ramos, L.; Shuaib, M.; Syed, S.H.; Lone, I.N.; Boopathi, R.; Fontaine, E.; Papai, G.; et al. The Flexible Ends of CENP-A Nucleosome Are Required for Mitotic Fidelity. Mol. Cell 2016, 63, 674-685. [CrossRef] [PubMed] 
56. Conde e Silva, N.; Black, B.E.; Sivolob, A.; Filipski, J.; Cleveland, D.W.; Prunell, A. CENP-A-containing nucleosomes: Easier disassembly versus exclusive centromeric localization. J. Mol. Biol. 2007, 370, 555-573. [CrossRef] [PubMed]

57. Hasson, D.; Panchenko, T.; Salimian, K.J.; Salman, M.U.; Sekulic, N.; Alonso, A.; Warburton, P.E.; Black, B.E. The octamer is the major form of CENP-A nucleosomes at human centromeres. Nat. Struct. Mol. Biol. 2013, 20,687-695. [CrossRef] [PubMed]

58. Panchenko, T.; Sorensen, T.C.; Woodcock, C.L.; Kan, Z.Y.; Wood, S.; Resch, M.G.; Luger, K.; Englander, S.W.; Hansen, J.C.; Black, B.E. Replacement of histone H3 with CENP-A directs global nucleosome array condensation and loosening of nucleosome superhelical termini. Proc. Natl. Acad. Sci. USA 2011, 108, 16588-16593. [CrossRef]

59. Takizawa, Y.; Ho, C.H.; Tachiwana, H.; Matsunami, H.; Kobayashi, W.; Suzuki, M.; Arimura, Y.; Hori, T.; Fukagawa, T.; Ohi, M.D.; et al. Cryo-EM Structures of Centromeric Tri-nucleosomes Containing a Central CENP-A Nucleosome. Structure 2020, 28, 44-53. [CrossRef]

60. Zhou, B.R.; Yadav, K.N.S.; Borgnia, M.; Hong, J.; Cao, B.; Olins, A.L.; Olins, D.E.; Bai, Y.; Zhang, P. Atomic resolution cryo-EM structure of a native-like CENP-A nucleosome aided by an antibody fragment. Nat. Commun. 2019, 10, 2301. [CrossRef]

61. Masumoto, H.; Masukata, H.; Muro, Y.; Nozaki, N.; Okazaki, T. A human centromere antigen (CENP-B) interacts with a short specific sequence in alphoid DNA, a human centromeric satellite. J. Cell Biol. 1989, 109, 1963-1973. [CrossRef]

62. Muro, Y.; Masumoto, H.; Yoda, K.; Nozaki, N.; Ohashi, M.; Okazaki, T. Centromere protein B assembles human centromeric $\alpha$-satellite DNA at the 17-bp sequence, CENP-B box. J. Cell Biol. 1992, 116, 585-596. [CrossRef]

63. Tanaka, Y.; Nureki, O.; Kurumizaka, H.; Fukai, S.; Kawaguchi, S.; Ikuta, M.; Iwahara, J.; Okazaki, T.; Yokoyama, S. Crystal structure of the CENP-B protein-DNA complex: The DNA-binding domains of CENP-B induce kinks in the CENP-B box DNA. EMBO J. 2001, 20, 6612-6618. [CrossRef] [PubMed]

64. Fachinetti, D.; Han, J.S.; McMahon, M.A.; Ly, P.; Abdullah, A.; Wong, A.J.; Cleveland, D.W. DNA Sequence-Specific Binding of CENP-B Enhances the Fidelity of Human Centromere Function. Dev. Cell 2015, 33, 314-327. [CrossRef] [PubMed]

65. Gamba, R.; Fachinetti, D. From evolution to function: Two sides of the same CENP-B coin? Exp. Cell Res. 2020, 111959. [CrossRef]

66. Hoffmann, S.; Dumont, M.; Barra, V.; Ly, P.; Nechemia-Arbely, Y.; McMahon, M.A.; Herve, S.; Cleveland, D.W.; Fachinetti, D. CENP-A Is Dispensable for Mitotic Centromere Function after Initial Centromere/Kinetochore Assembly. Cell Rep. 2016, 17, 2394-2404. [CrossRef] [PubMed]

67. Dumont, M.; Gamba, R.; Gestraud, P.; Klaasen, S.; Worrall, J.T.; De Vries, S.G.; Boudreau, V.; Salinas-Luypaert, C.; Maddox, P.S.; Lens, S.M.; et al. Human chromosome-specific aneuploidy is influenced by DNA-dependent centromeric features. EMBO J. 2020, 39, e102924. [CrossRef] [PubMed]

68. Tyler-Smith, C.; Gimelli, G.; Giglio, S.; Floridia, G.; Pandya, A.; Terzoli, G.; Warburton, P.E.; Earnshaw, W.C.; Zuffardi, O. Transmission of a fully functional human neocentromere through three generations. Am. J. Hum. Genet. 1999, 64, 1440-1444. [CrossRef]

69. Koren, A.; Tsai, H.J.; Tirosh, I.; Burrack, L.S.; Barkai, N.; Berman, J. Epigenetically-inherited centromere and neocentromere DNA replicates earliest in S-phase. PLoS Genet. 2010, 6, e1001068. [CrossRef]

70. Hori, T.; Fukagawa, T. Artificial generation of centromeres and kinetochores to understand their structure and function. Exp. Cell Res. 2020, 389, 111898. [CrossRef]

71. Hudson, D.F.; Fowler, K.J.; Earle, E.; Saffery, R.; Kalitsis, P.; Trowell, H.; Hill, J.; Wreford, N.G.; de Kretser, D.M.; Cancilla, M.R.; et al. Centromere protein B null mice are mitotically and meiotically normal but have lower body and testis weights. J. Cell Biol. 1998, 141, 309-319. [CrossRef] [PubMed]

72. Kapoor, M.; Montes de Oca Luna, R.; Liu, G.; Lozano, G.; Cummings, C.; Mancini, M.; Ouspenski, I.; Brinkley, B.R.; May, G.S. The cenpB gene is not essential in mice. Chromosoma 1998, 107, 570-576. [CrossRef] [PubMed]

73. Perez-Castro, A.V.; Shamanski, F.L.; Meneses, J.J.; Lovato, T.L.; Vogel, K.G.; Moyzis, R.K.; Pedersen, R. Centromeric protein B null mice are viable with no apparent abnormalities. Dev. Biol. 1998, 201, 135-143. [CrossRef] [PubMed] 
74. Foltz, D.R.; Jansen, L.E.; Black, B.E.; Bailey, A.O.; Yates, J.R.; Cleveland, D.W. The human CENP-A centromeric nucleosome-associated complex. Nat. Cell Biol. 2006, 8, 458-469. [CrossRef] [PubMed]

75. Hori, T.; Amano, M.; Suzuki, A.; Backer, C.B.; Welburn, J.P.; Dong, Y.; McEwen, B.F.; Shang, W.H.; Suzuki, E.; Okawa, K.; et al. CCAN makes multiple contacts with centromeric DNA to provide distinct pathways to the outer kinetochore. Cell 2008, 135, 1039-1052. [CrossRef]

76. Black, B.E.; Bassett, E.A. The histone variant CENP-A and centromere specification. Curr. Opin. Cell Biol. 2008, 20, 91-100. [CrossRef]

77. Allu, P.K.; Dawicki-McKenna, J.M.; Van Eeuwen, T.; Slavin, M.; Braitbard, M.; Xu, C.; Kalisman, N.; Murakami, K.; Black, B.E. Structure of the Human Core Centromeric Nucleosome Complex. Curr. Biol. 2019, 29, 2625-2639. [CrossRef]

78. Yan, K.; Yang, J.; Zhang, Z.; McLaughlin, S.H.; Chang, L.; Fasci, D.; Ehrenhofer-Murray, A.E.; Heck, A.J.R.; Barford, D. Structure of the inner kinetochore CCAN complex assembled onto a centromeric nucleosome. Nature 2019, 574, 278-282. [CrossRef]

79. Hara, M.; Fukagawa, T. Critical Foundation of the Kinetochore: The Constitutive Centromere-Associated Network (CCAN). Prog. Mol. Subcell Biol. 2017, 56, 29-57. [CrossRef]

80. Klare, K.; Weir, J.R.; Basilico, F.; Zimniak, T.; Massimiliano, L.; Ludwigs, N.; Herzog, F.; Musacchio, A. CENP-C is a blueprint for constitutive centromere-associated network assembly within human kinetochores. J. Cell Biol. 2015, 210, 11-22. [CrossRef]

81. Shono, N.; Ohzeki, J.; Otake, K.; Martins, N.M.; Nagase, T.; Kimura, H.; Larionov, V.; Earnshaw, W.C.; Masumoto, H. CENP-C and CENP-I are key connecting factors for kinetochore and CENP-A assembly. J. Cell Sci. 2015, 128, 4572-4587. [CrossRef] [PubMed]

82. Ali-Ahmad, A.; Bilokapic, S.; Schafer, I.B.; Halic, M.; Sekulic, N. CENP-C unwraps the human CENP-A nucleosome through the H2A C-terminal tail. EMBO Rep. 2019, 20, e48913. [CrossRef] [PubMed]

83. Falk, S.J.; Guo, L.Y.; Sekulic, N.; Smoak, E.M.; Mani, T.; Logsdon, G.A.; Gupta, K.; Jansen, L.E.T.; Van Duyne, G.D.; Vinogradov, S.A.; et al. CENP-C reshapes and stabilizes CENP-A nucleosomes at the centromere. Science 2015, 348, 699-703. [CrossRef]

84. Watanabe, R.; Hara, M.; Okumura, E.-I.; Hervé, S.; Fachinetti, D.; Ariyoshi, M.; Fukagawa, T. CDK1-mediated CENP-C phosphorylation modulates CENP-A binding and mitotic kinetochore localization. J. Cell Biol. 2019, 218, 4042-4062. [CrossRef] [PubMed]

85. Carroll, C.W.; Milks, K.J.; Straight, A.F. Dual recognition of CENP-A nucleosomes is required for centromere assembly. J. Cell Biol. 2010, 189, 1143-1155. [CrossRef] [PubMed]

86. Tachiwana, H.; Muller, S.; Blumer, J.; Klare, K.; Musacchio, A.; Almouzni, G. HJURP involvement in de novo CenH3 (CENP-A) and CENP-C recruitment. Cell Rep. 2015, 11, 22-32. [CrossRef] [PubMed]

87. McKinley, K.L.; Sekulic, N.; Guo, L.Y.; Tsinman, T.; Black, B.E.; Cheeseman, I.M. The CENP-L-N Complex Forms a Critical Node in an Integrated Meshwork of Interactions at the Centromere-Kinetochore Interface. Mol. Cell 2015, 60, 886-898. [CrossRef] [PubMed]

88. Carroll, C.W.; Silva, M.C.; Godek, K.M.; Jansen, L.E.; Straight, A.F. Centromere assembly requires the direct recognition of CENP-A nucleosomes by CENP-N. Nat. Cell Biol. 2009, 11, 896-902. [CrossRef]

89. Weir, J.R.; Faesen, A.C.; Klare, K.; Petrovic, A.; Basilico, F.; Fischbock, J.; Pentakota, S.; Keller, J.; Pesenti, M.E.; Pan, D.; et al. Insights from biochemical reconstitution into the architecture of human kinetochores. Nature 2016, 537, 249-253. [CrossRef]

90. Giunta, S.; Funabiki, H. Integrity of the human centromere DNA repeats is protected by CENP-A, CENP-C, and CENP-T. Proc. Natl. Acad. Sci. USA 2017, 114, 1928-1933. [CrossRef]

91. Basilico, F.; Maffini, S.; Weir, J.R.; Prumbaum, D.; Rojas, A.M.; Zimniak, T.; De Antoni, A.; Jeganathan, S.; Voss, B.; van Gerwen, S.; et al. The pseudo GTPase CENP-M drives human kinetochore assembly. eLife 2014, 3, e02978. [CrossRef] [PubMed]

92. Milks, K.J.; Moree, B.; Straight, A.F. Dissection of CENP-C-directed centromere and kinetochore assembly. Mol. Biol. Cell 2009, 20, 4246-4255. [CrossRef]

93. Kwon, M.S.; Hori, T.; Okada, M.; Fukagawa, T. CENP-C is involved in chromosome segregation, mitotic checkpoint function, and kinetochore assembly. Mol. Biol. Cell 2007, 18, 2155-2168. [CrossRef] [PubMed] 
94. Nagpal, H.; Hori, T.; Furukawa, A.; Sugase, K.; Osakabe, A.; Kurumizaka, H.; Fukagawa, T. Dynamic changes in CCAN organization through CENP-C during cell-cycle progression. Mol. Biol. Cell 2015, 26, 3768-3776. [CrossRef] [PubMed]

95. Fukagawa, T.; Brown, W.R.A. Efficient Conditional Mutation of the Vertebrate CENP-C Gene. Hum. Mol. Genet. 1997, 6, 2301-2308. [CrossRef] [PubMed]

96. Mitra, S.; Bodor, D.L.; David, A.F.; Abdul-Zani, I.; Mata, J.F.; Neumann, B.; Reither, S.; Tischer, C.; Jansen, L.E.T. Genetic screening identifies a SUMO protease dynamically maintaining centromeric chromatin. Nat. Commun. 2020, 11, 501. [CrossRef]

97. Liebelt, F.; Jansen, N.S.; Kumar, S.; Gracheva, E.; Claessens, L.A.; Verlaan-de Vries, M.; Willemstein, E.; Vertegaal, A.C.O. The poly-SUMO2/3 protease SENP6 enables assembly of the constitutive centromere-associated network by group deSUMOylation. Nat. Commun. 2019, 10, 3987. [CrossRef]

98. Nechemia-Arbely, Y.; Fachinetti, D.; Cleveland, D.W. Replicating centromeric chromatin: Spatial and temporal control of CENP-A assembly. Exp. Cell Res. 2012, 318, 1353-1360. [CrossRef]

99. Ten Hagen, K.G.; Gilbert, D.M.; Willard, H.F.; Cohen, S.N. Replication timing of DNA sequences associated with human centromeres and telomeres. Mol. Cell Biol. 1990, 10, 6348-6355. [CrossRef]

100. Jansen, L.E.; Black, B.E.; Foltz, D.R.; Cleveland, D.W. Propagation of centromeric chromatin requires exit from mitosis. J. Cell Biol. 2007, 176, 795-805. [CrossRef]

101. Schuh, M.; Lehner, C.F.; Heidmann, S. Incorporation of Drosophila CID/CENP-A and CENP-C into centromeres during early embryonic anaphase. Curr. Biol. 2007, 17, 237-243. [CrossRef] [PubMed]

102. Foltz, D.R.; Jansen, L.E.; Bailey, A.O.; Yates, J.R.; Bassett, E.A.; Wood, S.; Black, B.E.; Cleveland, D.W. Centromere-specific assembly of CENP-a nucleosomes is mediated by HJURP. Cell 2009, 137, 472-484. [CrossRef]

103. Dunleavy, E.M.; Roche, D.; Tagami, H.; Lacoste, N.; Ray-Gallet, D.; Nakamura, Y.; Daigo, Y.; Nakatani, Y.; Almouzni-Pettinotti, G. HJURP is a cell-cycle-dependent maintenance and deposition factor of CENP-A at centromeres. Cell 2009, 137, 485-497. [CrossRef] [PubMed]

104. Silva, M.C.; Bodor, D.L.; Stellfox, M.E.; Martins, N.M.; Hochegger, H.; Foltz, D.R.; Jansen, L.E. Cdk activity couples epigenetic centromere inheritance to cell cycle progression. Dev. Cell 2012, 22, 52-63. [CrossRef]

105. Stankovic, A.; Guo, L.Y.; Mata, J.F.; Bodor, D.L.; Cao, X.J.; Bailey, A.O.; Shabanowitz, J.; Hunt, D.F.; Garcia, B.A.; Black, B.E.; et al. A Dual Inhibitory Mechanism Sufficient to Maintain Cell-Cycle-Restricted CENP-A Assembly. Mol. Cell 2017, 65, 231-246. [CrossRef]

106. Fujita, Y.; Hayashi, T.; Kiyomitsu, T.; Toyoda, Y.; Kokubu, A.; Obuse, C.; Yanagida, M. Priming of centromere for CENP-A recruitment by human hMis18alpha, hMis18beta, and M18BP1. Dev. Cell 2007, 12, 17-30. [CrossRef] [PubMed]

107. Silva, M.C.; Jansen, L.E. At the right place at the right time: Novel CENP-A binding proteins shed light on centromere assembly. Chromosoma 2009, 118, 567-574. [CrossRef]

108. Hayashi, T.; Fujita, Y.; Iwasaki, O.; Adachi, Y.; Takahashi, K.; Yanagida, M. Mis16 and Mis18 are required for CENP-A loading and histone deacetylation at centromeres. Cell 2004, 118, 715-729. [CrossRef]

109. Maddox, P.S.; Hyndman, F.; Monen, J.; Oegema, K.; Desai, A. Functional genomics identifies a Myb domain-containing protein family required for assembly of CENP-A chromatin. J. Cell Biol. 2007, 176, 757-763. [CrossRef]

110. McKinley, K.L.; Cheeseman, I.M. Polo-like kinase 1 licenses CENP-A deposition at centromeres. Cell 2014, 158, 397-411. [CrossRef]

111. Moree, B.; Meyer, C.B.; Fuller, C.J.; Straight, A.F. CENP-C recruits M18BP1 to centromeres to promote CENP-A chromatin assembly. J. Cell Biol. 2011, 194, 855-871. [CrossRef] [PubMed]

112. Stellfox, M.E.; Nardi, I.K.; Knippler, C.M.; Foltz, D.R. Differential Binding Partners of the Mis18 $\alpha / \beta$ YIPPEE Domains Regulate Mis18 Complex Recruitment to Centromeres. Cell Rep. 2016, 15, 2127-2135. [CrossRef] [PubMed]

113. Nardi, I.K.; Zasadzinska, E.; Stellfox, M.E.; Knippler, C.M.; Foltz, D.R. Licensing of Centromeric Chromatin Assembly through the Mis18 $\alpha$-Mis18 $\beta$ Heterotetramer. Mol. Cell 2016, 61, 774-787. [CrossRef] [PubMed]

114. Pan, D.; Klare, K.; Petrovic, A.; Take, A.; Walstein, K.; Singh, P.; Rondelet, A.; Bird, A.W.; Musacchio, A. CDK-regulated dimerization of M18BP1 on a Mis18 hexamer is necessary for CENP-A loading. eLife 2017, 6, e23352. [CrossRef] [PubMed] 
115. Spiller, F.; Medina-Pritchard, B.; Abad, M.A.; Wear, M.A.; Molina, O.; Earnshaw, W.C.; Jeyaprakash, A.A. Molecular basis for Cdk1-regulated timing of Mis18 complex assembly and CENP-A deposition. EMBO Rep. 2017, 18, 894-905. [CrossRef]

116. Pan, D.; Walstein, K.; Take, A.; Bier, D.; Kaiser, N.; Musacchio, A. Mechanism of centromere recruitment of the CENP-A chaperone HJURP and its implications for centromere licensing. Nat. Commun. 2019, 10, 4046. [CrossRef]

117. Zasadzinska, E.; Barnhart-Dailey, M.C.; Kuich, P.H.; Foltz, D.R. Dimerization of the CENP-A assembly factor HJURP is required for centromeric nucleosome deposition. EMBO J. 2013, 32, 2113-2124. [CrossRef]

118. Wang, J.; Liu, X.; Dou, Z.; Chen, L.; Jiang, H.; Fu, C.; Fu, G.; Liu, D.; Zhang, J.; Zhu, T.; et al. Mitotic regulator Mis18beta interacts with and specifies the centromeric assembly of molecular chaperone holliday junction recognition protein (HJURP). J. Biol. Chem. 2014, 289, 8326-8336. [CrossRef]

119. Pidoux, A.L.; Choi, E.S.; Abbott, J.K.; Liu, X.; Kagansky, A.; Castillo, A.G.; Hamilton, G.L.; Richardson, W.; Rappsilber, J.; He, X.; et al. Fission yeast Scm3: A CENP-A receptor required for integrity of subkinetochore chromatin. Mol. Cell 2009, 33, 299-311. [CrossRef]

120. Bassett, E.A.; DeNizio, J.; Barnhart-Dailey, M.C.; Panchenko, T.; Sekulic, N.; Rogers, D.J.; Foltz, D.R.; Black, B.E. HJURP uses distinct CENP-A surfaces to recognize and to stabilize CENP-A/histone H4 for centromere assembly. Dev. Cell 2012, 22, 749-762. [CrossRef]

121. Perpelescu, M.; Nozaki, N.; Obuse, C.; Yang, H.; Yoda, K. Active establishment of centromeric CENP-A chromatin by RSF complex. J. Cell Biol. 2009, 185, 397-407. [CrossRef] [PubMed]

122. Lagana, A.; Dorn, J.F.; De Rop, V.; Ladouceur, A.M.; Maddox, A.S.; Maddox, P.S. A small GTPase molecular switch regulates epigenetic centromere maintenance by stabilizing newly incorporated CENP-A. Nat. Cell Biol. 2010, 12, 1186-1193. [CrossRef] [PubMed]

123. Stellfox, M.E.; Bailey, A.O.; Foltz, D.R. Putting CENP-A in its place. Cell Mol. Life Sci. 2013, 70, $387-406$. [CrossRef] [PubMed]

124. Shelby, R.D.; Monier, K.; Sullivan, K.F. Chromatin assembly at kinetochores is uncoupled from DNA replication. J. Cell Biol. 2000, 151, 1113-1118. [CrossRef] [PubMed]

125. Shelby, R.D.; Vafa, O.; Sullivan, K.F. Assembly of CENP-A into centromeric chromatin requires a cooperative array of nucleosomal DNA contact sites. J. Cell Biol. 1997, 136, 501-513. [CrossRef]

126. Miga, K.H.; Newton, Y.; Jain, M.; Altemose, N.; Willard, H.F.; Kent, W.J. Centromere reference models for human chromosomes $X$ and $Y$ satellite arrays. Genome Res. 2014, 24, 697-707. [CrossRef]

127. Schneider, V.A.; Graves-Lindsay, T.; Howe, K.; Bouk, N.; Chen, H.C.; Kitts, P.A.; Murphy, T.D.; Pruitt, K.D.; Thibaud-Nissen, F.; Albracht, D.; et al. Evaluation of GRCh38 and de novo haploid genome assemblies demonstrates the enduring quality of the reference assembly. Genome Res. 2017, 27, 849-864. [CrossRef]

128. Levy, S.; Sutton, G.; Ng, P.C.; Feuk, L.; Halpern, A.L.; Walenz, B.P.; Axelrod, N.; Huang, J.; Kirkness, E.F.; Denisov, G.; et al. The diploid genome sequence of an individual human. PLoS Biol. 2007, 5, e254. [CrossRef]

129. Huang, H.; Stromme, C.B.; Saredi, G.; Hodl, M.; Strandsby, A.; Gonzalez-Aguilera, C.; Chen, S.; Groth, A.; Patel, D.J. A unique binding mode enables MCM2 to chaperone histones H3-H4 at replication forks. Nat. Struct. Mol. Biol. 2015, 22, 618-626. [CrossRef]

130. Smith, S.; Stillman, B. Stepwise assembly of chromatin during DNA replication in vitro. EMBO J. 1991, 10, 971-980. [CrossRef]

131. Richet, N.; Liu, D.; Legrand, P.; Velours, C.; Corpet, A.; Gaubert, A.; Bakail, M.; Moal-Raisin, G.; Guerois, R.; Compper, C.; et al. Structural insight into how the human helicase subunit MCM2 may act as a histone chaperone together with ASF1 at the replication fork. Nucleic Acids Res. 2015, 43, 1905-1917. [CrossRef] [PubMed]

132. Zasadzinska, E.; Huang, J.; Bailey, A.O.; Guo, L.Y.; Lee, N.S.; Srivastava, S.; Wong, K.A.; French, B.T.; Black, B.E.; Foltz, D.R. Inheritance of CENP-A Nucleosomes during DNA Replication Requires HJURP. Dev. Cell 2018, 47, 348-362. [CrossRef]

133. Dunleavy, E.M.; Almouzni, G.; Karpen, G.H. H3.3 is deposited at centromeres in S phase as a placeholder for newly assembled CENP-A in G (1) phase. Nucleus 2011, 2, 146-157. [CrossRef] [PubMed]

134. Shukla, M.; Tong, P.; White, S.A.; Singh, P.P.; Reid, A.M.; Catania, S.; Pidoux, A.L.; Allshire, R.C. Centromere DNA Destabilizes H3 Nucleosomes to Promote CENP-A Deposition during the Cell Cycle. Curr. Biol. 2018, 28, 3924-3936. [CrossRef] 
135. Athwal, R.K.; Walkiewicz, M.P.; Baek, S.; Fu, S.; Bui, M.; Camps, J.; Ried, T.; Sung, M.H.; Dalal, Y. CENP-A nucleosomes localize to transcription factor hotspots and subtelomeric sites in human cancer cells. Epigenet. Chromatin 2015, 8, 2. [CrossRef] [PubMed]

136. Van Hooser, A.A.; Ouspenski, I.I.; Gregson, H.C.; Starr, D.A.; Yen, T.J.; Goldberg, M.L.; Yokomori, K.; Earnshaw, W.C.; Sullivan, K.F.; Brinkley, B.R. Specification of kinetochore-forming chromatin by the histone H3 variant CENP-A. J. Cell Sci. 2001, 114, 3529-3542.

137. Shrestha, R.L.; Ahn, G.S.; Staples, M.I.; Sathyan, K.M.; Karpova, T.S.; Foltz, D.R.; Basrai, M.A. Mislocalization of centromeric histone H3 variant CENP-A contributes to chromosomal instability (CIN) in human cells. Oncotarget 2017, 8, 46781-46800. [CrossRef]

138. Filipescu, D.; Naughtin, M.; Podsypanina, K.; Lejour, V.; Wilson, L.; Gurard-Levin, Z.A.; Orsi, G.A.; Simeonova, I.; Toufektchan, E.; Attardi, L.D.; et al. Essential role for centromeric factors following p53 loss and oncogenic transformation. Genes Dev. 2017, 31, 463-480. [CrossRef]

139. Au, W.-C.; Zhang, T.; Mishra, P.K.; Eisenstatt, J.R.; Walker, R.L.; Ocampo, J.; Dawson, A.; Warren, J.; Costanzo, M.; Baryshnikova, A.; et al. Skp, Cullin, F-box (SCF)-Met30 and SCF-Cdc4-Mediated Proteolysis of CENP-A Prevents Mislocalization of CENP-A for Chromosomal Stability in Budding Yeast. PLOS Genet. 2020, 16, e1008597. [CrossRef]

140. Hewawasam, G.; Shivaraju, M.; Mattingly, M.; Venkatesh, S.; Martin-Brown, S.; Florens, L.; Workman, J.L.; Gerton, J.L. Psh1 is an E3 ubiquitin ligase that targets the centromeric histone variant Cse4. Mol. Cell 2010, 40, 444-454. [CrossRef]

141. Ranjitkar, P.; Press, M.O.; Yi, X.; Baker, R.; MacCoss, M.J.; Biggins, S. An E3 ubiquitin ligase prevents ectopic localization of the centromeric histone H3 variant via the centromere targeting domain. Mol. Cell 2010, 40, 455-464. [CrossRef] [PubMed]

142. Hewawasam, G.S.; Mattingly, M.; Venkatesh, S.; Zhang, Y.; Florens, L.; Workman, J.L.; Gerton, J.L. Phosphorylation by casein kinase 2 facilitates Psh1 protein-assisted degradation of Cse4 protein. J. Biol. Chem. 2014, 289, 29297-29309. [CrossRef] [PubMed]

143. Cheng, H.; Bao, X.; Rao, H. The F-box Protein Rcy1 Is Involved in the Degradation of Histone H3 Variant Cse4 and Genome Maintenance. J. Biol. Chem. 2016, 291, 10372-10377. [CrossRef] [PubMed]

144. Ohkuni, K.; Takahashi, Y.; Fulp, A.; Lawrimore, J.; Au, W.C.; Pasupala, N.; Levy-Myers, R.; Warren, J.; Strunnikov, A.; Baker, R.E.; et al. SUMO-Targeted Ubiquitin Ligase (STUbL) Slx5 regulates proteolysis of centromeric histone H3 variant Cse4 and prevents its mislocalization to euchromatin. Mol. Biol. Cell 2016. [CrossRef] [PubMed]

145. Kitagawa, T.; Ishii, K.; Takeda, K.; Matsumoto, T. The $19 \mathrm{~S}$ proteasome subunit Rpt3 regulates distribution of CENP-A by associating with centromeric chromatin. Nat. Commun. 2014, 5, 3597. [CrossRef]

146. Moreno-Moreno, O.; Torras-Llort, M.; Azorin, F. Proteolysis restricts localization of CID, the centromere-specific histone H3 variant of Drosophila, to centromeres. Nucleic Acids Res. 2006, 34, 6247-6255. [CrossRef]

147. Moreno-Moreno, O.; Medina-Giro, S.; Torras-Llort, M.; Azorin, F. The F box protein partner of paired regulates stability of Drosophila centromeric histone H3, CenH3(CID). Curr. Biol. 2011, 21, 1488-1493. [CrossRef]

148. Sun, X.; Clermont, P.L.; Jiao, W.; Helgason, C.D.; Gout, P.W.; Wang, Y.; Qu, S. Elevated expression of the centromere protein-A (CENP-A)-encoding gene as a prognostic and predictive biomarker in human cancers. Int. J. Cancer 2016, 139, 899-907. [CrossRef]

149. Gu, X.M.; Fu, J.; Feng, X.J.; Huang, X.; Wang, S.M.; Chen, X.F.; Zhu, M.H.; Zhang, S.H. Expression and prognostic relevance of centromere protein A in primary osteosarcoma. Pathol. Res. Pract. 2014, 210, 228-233. [CrossRef]

150. Mahler, M.; You, D.; Baron, M.; Taillefer, S.S.; Hudson, M.; Canadian Scleroderma Research, Group; Fritzler, M.J. Anti-centromere antibodies in a large cohort of systemic sclerosis patients: Comparison between immunofluorescence, CENP-A and CENP-B ELISA. Clin Chim Acta 2011, 412, 1937-1943. [CrossRef]

151. Qiu, J.J.; Guo, J.J.; Lv, T.J.; Jin, H.Y.; Ding, J.X.; Feng, W.W.; Zhang, Y.; Hua, K.Q. Prognostic value of centromere protein-A expression in patients with epithelial ovarian cancer. Tumour Biol. 2013, 34, 2971-2975. [CrossRef] [PubMed] 
152. Wu, Q.; Qian, Y.M.; Zhao, X.L.; Wang, S.M.; Feng, X.J.; Chen, X.F.; Zhang, S.H. Expression and prognostic significance of centromere protein A in human lung adenocarcinoma. Lung Cancer 2012, 77, 407-414. [CrossRef]

153. McGovern, S.L.; Qi, Y.; Pusztai, L.; Symmans, W.F.; Buchholz, T.A. Centromere protein-A, an essential centromere protein, is a prognostic marker for relapse in estrogen receptor-positive breast cancer. Breast Cancer Res. 2012, 14, R72. [CrossRef] [PubMed]

154. Ly, P.; Teitz, L.S.; Kim, D.H.; Shoshani, O.; Skaletsky, H.; Fachinetti, D.; Page, D.C.; Cleveland, D.W. Selective $\mathrm{Y}$ centromere inactivation triggers chromosome shattering in micronuclei and repair by non-homologous end joining. Nat. Cell Biol. 2017, 19, 68-75. [CrossRef] [PubMed]

155. Umbreit, N.T.; Zhang, C.Z.; Lynch, L.D.; Blaine, L.J.; Cheng, A.M.; Tourdot, R.; Sun, L.; Almubarak, H.F.; Judge, K.; Mitchell, T.J.; et al. Mechanisms generating cancer genome complexity from a single cell division error. Science 2020, 368. [CrossRef] [PubMed]

156. Ly, P.; Brunner, S.F.; Shoshani, O.; Kim, D.H.; Lan, W.; Pyntikova, T.; Flanagan, A.M.; Behjati, S.; Page, D.C.; Campbell, P.J.; et al. Chromosome segregation errors generate a diverse spectrum of simple and complex genomic rearrangements. Nat. Genet. 2019, 51, 705-715. [CrossRef] [PubMed]

157. Ly, P.; Cleveland, D.W. Rebuilding Chromosomes After Catastrophe: Emerging Mechanisms of Chromothripsis. Trends Cell Biol. 2017, 27, 917-930. [CrossRef]

158. Zhang, W.; Mao, J.H.; Zhu, W.; Jain, A.K.; Liu, K.; Brown, J.B.; Karpen, G.H. Centromere and kinetochore gene misexpression predicts cancer patient survival and response to radiotherapy and chemotherapy. Nat. Commun. 2016, 7, 12619. [CrossRef]

159. Cimini, D. Merotelic kinetochore orientation, aneuploidy, and cancer. Biochim. Biophys. Acta 2008, 1786, 32-40. [CrossRef]

160. Taylor, A.M.; Shih, J.; Ha, G.; Gao, G.F.; Zhang, X.; Berger, A.C.; Schumacher, S.E.; Wang, C.; Hu, H.; Liu, J.; et al. Genomic and Functional Approaches to Understanding Cancer Aneuploidy. Cancer Cell 2018, 33, 676-689. [CrossRef]

161. Takada, M.; Zhang, W.; Suzuki, A.; Kuroda, T.S.; Yu, Z.; Inuzuka, H.; Gao, D.; Wan, L.; Zhuang, M.; Hu, L.; et al. FBW7 Loss Promotes Chromosomal Instability and Tumorigenesis via Cyclin E1/CDK2-Mediated Phosphorylation of CENP-A. Cancer Res. 2017, 77, 4881-4893. [CrossRef] [PubMed]

162. Davoli, T.; Uno, H.; Wooten, E.C.; Elledge, S.J. Tumor aneuploidy correlates with markers of immune evasion and with reduced response to immunotherapy. Science 2017, 355. [CrossRef] [PubMed]

163. Laughney, A.M.; Elizalde, S.; Genovese, G.; Bakhoum, S.F. Dynamics of Tumor Heterogeneity Derived from Clonal Karyotypic Evolution. Cell Rep. 2015, 12, 809-820. [CrossRef]

164. Shih, I.M.; Zhou, W.; Goodman, S.N.; Lengauer, C.; Kinzler, K.W.; Vogelstein, B. Evidence that genetic instability occurs at an early stage of colorectal tumorigenesis. Cancer Res. 2001, 61, 818-822.

165. Turajlic, S.; Swanton, C. Implications of cancer evolution for drug development. Nat. Rev. Drug Discov. 2017, 16, 441-442. [CrossRef] [PubMed]

166. Cimini, D.; Howell, B.; Maddox, P.; Khodjakov, A.; Degrassi, F.; Salmon, E.D. Merotelic kinetochore orientation is a major mechanism of aneuploidy in mitotic mammalian tissue cells. J. Cell Biol. 2001, 153, 517-527. [CrossRef] [PubMed]

167. Crasta, K.; Ganem, N.J.; Dagher, R.; Lantermann, A.B.; Ivanova, E.V.; Pan, Y.; Nezi, L.; Protopopov, A.; Chowdhury, D.; Pellman, D. DNA breaks and chromosome pulverization from errors in mitosis. Nature 2012, 482, 53-58. [CrossRef]

168. Levine, M.S.; Holland, A.J. The impact of mitotic errors on cell proliferation and tumorigenesis. Genes Dev. 2018, 32, 620-638. [CrossRef]

169. Elsasser, S.J.; D'Arcy, S. Towards a mechanism for histone chaperones. Biochim. Biophys. Acta 2013, 1819, 211-221. [CrossRef]

170. Demirdizen, E.; Spiller-Becker, M.; Förtsch, A.; Wilhelm, A.; Corless, S.; Bade, D.; Bergner, A.; Hessling, B.; Erhardt, S. Localization of Drosophila CENP-A to non-centromeric sites depends on the NuRD complex. Nucleic Acids Res. 2019, 47, 11589-11608. [CrossRef]

171. Nye, J.; Sturgill, D.; Athwal, R.; Dalal, Y. HJURP antagonizes CENP-A mislocalization driven by the H3.3 chaperones HIRA and DAXX. PLoS ONE 2018, 13, e0205948. [CrossRef] [PubMed] 
172. Hu, Z.; Huang, G.; Sadanandam, A.; Gu, S.; Lenburg, M.E.; Pai, M.; Bayani, N.; Blakely, E.A.; Gray, J.W.; Mao, J.H. The expression level of HJURP has an independent prognostic impact and predicts the sensitivity to radiotherapy in breast cancer. Breast Cancer Res. 2010, 12, R18. [CrossRef] [PubMed]

173. Uhlen, M.; Zhang, C.; Lee, S.; Sjostedt, E.; Fagerberg, L.; Bidkhori, G.; Benfeitas, R.; Arif, M.; Liu, Z.; Edfors, F.; et al. A pathology atlas of the human cancer transcriptome. Science 2017, 357. [CrossRef] [PubMed]

174. Uhlen, M.; Fagerberg, L.; Hallstrom, B.M.; Lindskog, C.; Oksvold, P.; Mardinoglu, A.; Sivertsson, A.; Kampf, C.; Sjostedt, E.; Asplund, A.; et al. Proteomics. Tissue-based map of the human proteome. Science 2015, 347, 1260419. [CrossRef] [PubMed]

175. Kemp, C.J.; Moore, J.M.; Moser, R.; Bernard, B.; Teater, M.; Smith, L.E.; Rabaia, N.A.; Gurley, K.E.; Guinney, J.; Busch, S.E.; et al. CTCF haploinsufficiency destabilizes DNA methylation and predisposes to cancer. Cell Rep. 2014, 7, 1020-1029. [CrossRef]

176. Katainen, R.; Dave, K.; Pitkanen, E.; Palin, K.; Kivioja, T.; Valimaki, N.; Gylfe, A.E.; Ristolainen, H.; Hanninen, U.A.; Cajuso, T.; et al. CTCF/cohesin-binding sites are frequently mutated in cancer. Nat. Genet. 2015, 47, 818-821. [CrossRef]

177. Aitken, S.J.; Ibarra-Soria, X.; Kentepozidou, E.; Flicek, P.; Feig, C.; Marioni, J.C.; Odom, D.T. CTCF maintains regulatory homeostasis of cancer pathways. Genome Biol. 2018, 19, 106. [CrossRef]

178. Docquier, F.; Farrar, D.; D’Arcy, V.; Chernukhin, I.; Robinson, A.F.; Loukinov, D.; Vatolin, S.; Pack, S.; Mackay, A.; Harris, R.A.; et al. Heightened expression of CTCF in breast cancer cells is associated with resistance to apoptosis. Cancer Res. 2005, 65, 5112-5122. [CrossRef]

179. Li, Y.; Zhu, Z.; Zhang, S.; Yu, D.; Yu, H.; Liu, L.; Cao, X.; Wang, L.; Gao, H.; Zhu, M. ShRNA-targeted centromere protein A inhibits hepatocellular carcinoma growth. PLoS ONE 2011, 6, e17794. [CrossRef]

180. Sathyan, K.M.; Fachinetti, D.; Foltz, D.R. $\alpha$-amino trimethylation of CENP-A by NRMT is required for full recruitment of the centromere. Nat. Commun. 2017, 8, 14678. [CrossRef]

181. Zeitlin, S.G.; Shelby, R.D.; Sullivan, K.F. CENP-A is phosphorylated by Aurora B kinase and plays an unexpected role in completion of cytokinesis. J. Cell Biol. 2001, 155, 1147-1157. [CrossRef] [PubMed]

182. Barra, V.; Logsdon, G.A.; Scelfo, A.; Hoffmann, S.; Herve, S.; Aslanian, A.; Nechemia-Arbely, Y.; Cleveland, D.W.; Black, B.E.; Fachinetti, D. Phosphorylation of CENP-A on serine 7 does not control centromere function. Nat. Commun. 2019, 10, 175. [CrossRef] [PubMed]

183. Bailey, A.O.; Panchenko, T.; Sathyan, K.M.; Petkowski, J.J.; Pai, P.J.; Bai, D.L.; Russell, D.H.; Macara, I.G.; Shabanowitz, J.; Hunt, D.F.; et al. Posttranslational modification of CENP-A influences the conformation of centromeric chromatin. Proc. Natl. Acad Sci. USA 2013, 110, 11827-11832. [CrossRef] [PubMed]

184. Yu, Z.; Zhou, X.; Wang, W.; Deng, W.; Fang, J.; Hu, H.; Wang, Z.; Li, S.; Cui, L.; Shen, J.; et al. Dynamic phosphorylation of CENP-A at Ser68 orchestrates its cell-cycle-dependent deposition at centromeres. Dev. Cell 2015, 32, 68-81. [CrossRef]

185. Fachinetti, D.; Logsdon, G.A.; Abdullah, A.; Selzer, E.B.; Cleveland, D.W.; Black, B.E. CENP-A Modifications on Ser68 and Lys124 Are Dispensable for Establishment, Maintenance, and Long-Term Function of Human Centromeres. Dev. Cell 2017, 40, 104-113. [CrossRef]

186. Niikura, Y.; Kitagawa, R.; Ogi, H.; Abdulle, R.; Pagala, V.; Kitagawa, K. CENP-A K124 Ubiquitylation Is Required for CENP-A Deposition at the Centromere. Dev. Cell 2015, 32, 589-603. [CrossRef]

187. Niikura, Y.; Kitagawa, R.; Kitagawa, K. CENP-A Ubiquitylation Contributes to Maintaining the Chromosomal Location of the Centromere. Molecules 2019, 24, 402. [CrossRef]

188. Niikura, Y.; Kitagawa, R.; Fang, L.; Kitagawa, K. CENP-A Ubiquitylation Is Indispensable to Cell Viability. Dev. Cell 2019, 50, 683-689. [CrossRef]

189. Bui, M.; Pitman, M.; Nuccio, A.; Roque, S.; Donlin-Asp, P.G.; Nita-Lazar, A.; Papoian, G.A.; Dalal, Y. Internal modifications in the CENP-A nucleosome modulate centromeric dynamics. Epigenet. Chromatin 2017, 10, 17. [CrossRef]

190. Srivastava, S.; Foltz, D.R. Posttranslational modifications of CENP-A: Marks of distinction. Chromosoma 2018, 127, 279-290. [CrossRef]

191. Davis, R.J.; Welcker, M.; Clurman, B.E. Tumor suppression by the Fbw7 ubiquitin ligase: Mechanisms and opportunities. Cancer Cell 2014, 26, 455-464. [CrossRef] [PubMed] 
192. Wang, I.-C.; Chen, Y.-J.; Hughes, D.; Petrovic, V.; Major, M.L.; Park, H.J.; Tan, Y.; Ackerson, T.; Costa, R.H. Forkhead Box M1 Regulates the Transcriptional Network of Genes Essential for Mitotic Progression and Genes Encoding the SCF (Skp2-Cks1) Ubiquitin Ligase. Mol. Cell. Biol. 2005, 25, 10875-10894. [CrossRef] [PubMed]

193. Wonsey, D.R.; Follettie, M.T. Loss of the Forkhead Transcription Factor FoxM1 Causes Centrosome Amplification and Mitotic Catastrophe. Cancer Res. 2005, 65, 5181-5189. [CrossRef] [PubMed]

194. Bade, D.; Pauleau, A.L.; Wendler, A.; Erhardt, S. The E3 ligase CUL3/RDX controls centromere maintenance by ubiquitylating and stabilizing CENP-A in a CAL1-dependent manner. Dev. Cell 2014, 28, 508-519. [CrossRef] [PubMed]

195. Wu, Q.; Chen, Y.F.; Fu, J.; You, Q.H.; Wang, S.M.; Huang, X.; Feng, X.J.; Zhang, S.H. Short hairpin RNA-mediated down-regulation of CENP-A attenuates the aggressive phenotype of lung adenocarcinoma cells. Cell Oncol. 2014, 37, 399-407. [CrossRef]

196. Cao, R.; Wang, G.; Qian, K.; Chen, L.; Qian, G.; Xie, C.; Dan, H.C.; Jiang, W.; Wu, M.; Wu, C.L.; et al. Silencing of HJURP induces dysregulation of cell cycle and ROS metabolism in bladder cancer cells via PPARgamma-SIRT1 feedback loop. J. Cancer 2017, 8, 2282-2295. [CrossRef]

(C) 2020 by the authors. Licensee MDPI, Basel, Switzerland. This article is an open access article distributed under the terms and conditions of the Creative Commons Attribution (CC BY) license (http://creativecommons.org/licenses/by/4.0/). 